\title{
Photophysical activity and host-guest behavior of ruthenium polypyridyl catalysts encapsulated in cucurbit[10]uril
}

Ena T. Luis, ${ }^{a *}$ Anthony I. Day, ${ }^{b}$ Burkhard König ${ }^{c}$ and Jonathon E. Beves ${ }^{a *}$

${ }^{a}$ School of Chemistry, UNSW Sydney, Sydney, Australia

${ }^{\mathrm{b}}$ School of Physical, Environmental and Mathematical Sciences, UNSW Canberra, Canberra, Australia

${ }^{c}$ Institute of Organic Chemistry, Faculty of Chemistry and Pharmacy, University of Regensburg, Germany

*e.luis@unsw.edu.au; j.beves@unsw.edu.au 


\section{CONTENTS}

S1. GENERAL METHODS 3

S2. SYNTHESIS 4

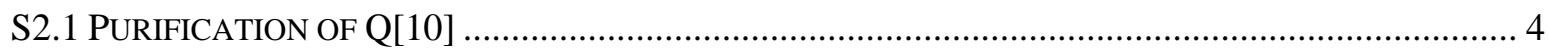

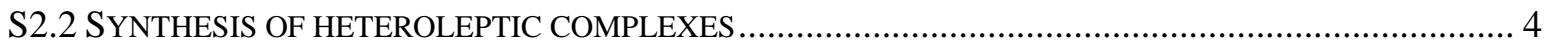

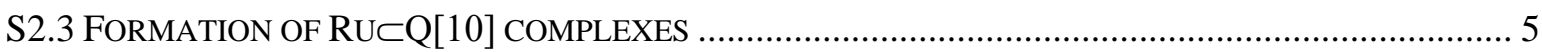

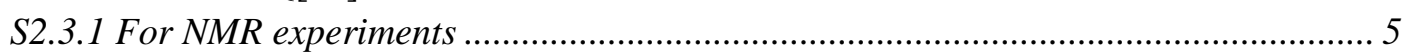

S2.3.2 For photophysical or electrochemical measurements........................................... 6

S2.4 SCREENING OF SUBSTRATES FOR THE FORMATION OF TERNARY COMPLEXES BY ${ }^{1} \mathrm{H}$ NMR

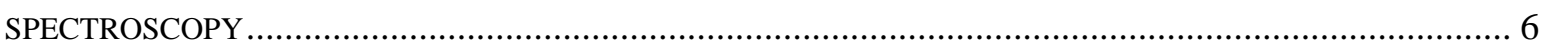

S3. ${ }^{1}$ H NMR SPECTROSCOPY DATA $\quad 7$

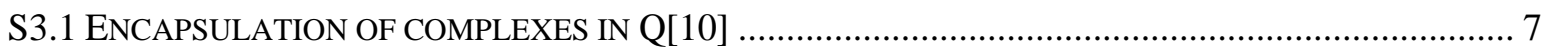

S3.2 PARTIAL ENCAPSULATION WITH SUBSTOICHIOMETRIC Q[10] ............................................ 9

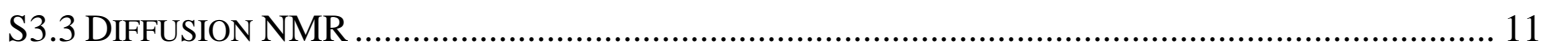

S4. HR-ESI-MS DATA 17

S5. ADDITIONAL PHOTOPHYSICAL DATA 19

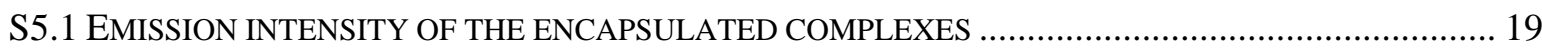

S5.2 EMISSION BEHAVIOR IN THE PRESENCE OF ADDED ACID OR BASE ........................................... 21

S5.3 DATA FOR STERN-VOLMER QUENCHING OF [RU(BPY $\left.)_{3}\right]^{2+}$ BY METHYL VIOLOGEN.................... 24

S6. ELECTROCHEMICAL DATA

S6.1 OXIDATION POTENTIALS OF THE COMPLEXES ...................................................................... 25

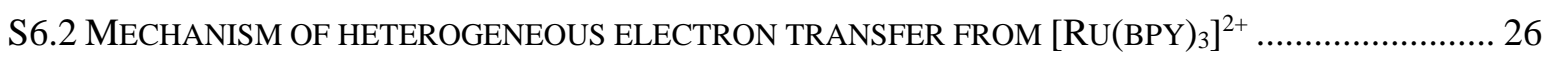

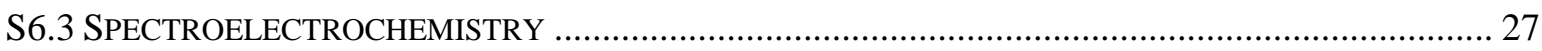

S7. SUBSTRATE BINDING 2

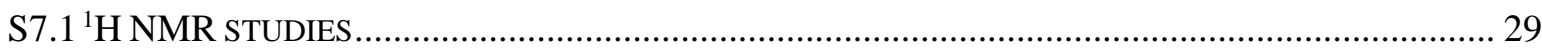

S7.2 INTERACTIONS WITHIN Q[10] WITH BOUND [RU(BPY) $\left.]_{3}\right]^{2+}$ AND 4-TERT-BUTYLBENZYLAMINE 34

S8. DIPHENYLIODONIUM AS A CATALYSIS SUBSTRATE

S8.1 STERN-VOLMER QUENCHING OF $\left[\mathrm{RU}(\mathrm{BPY})_{3}\right]^{2+}$ BY DIPHENYLIODONIUM ……......................... 35

S9. REFERENCES 36 


\section{S1. General methods}

NMR spectra were recorded at $298 \mathrm{~K}$ on a Bruker Avance $400 \mathrm{MHz}$ spectrometer. The chemical shifts for the ${ }^{1} \mathrm{H}$ NMR spectra are referenced to residual solvent resonance. Coupling constants $(J)$ are reported in hertz $(\mathrm{Hz})$. High-resolution mass spectrometry experiments were performed on a hybrid linear quadrupole ion trap mass spectrometer (Thermo LTQ Orbitrap XL) equipped with an external electrospray ionization (ESI) source.

UV-Vis absorption spectra were recorded on a Varian Cary 100 spectrophotometer. Corrected emission spectra were recorded on a Horiba Fluoromax-4 Spectrofluorometer or a Horiba Duetta Spectrometer. Excited state decays were measured on a Horiba DeltaPro TCSPC Lifetime Fluorometer equipped with a $452 \mathrm{~nm}$ DeltaDiode laser excitation source and were fit to exponential decays using DAS6 analysis software. Degassed measurements were made using screw-cap cuvettes and solutions were sparged with nitrogen or argon for ten minutes before each measurement.

Electrochemical measurements in water were recorded using an Autolab PGSTAT302N potentiostat. The solutions contained $0.1 \mathrm{M}$ phosphate buffer $(\mathrm{pH} 7)$ as the supporting electrolyte. A glassy carbon electrode, platinum wire and $\mathrm{Ag} / \mathrm{AgCl}(\mathrm{NaCl}, 3 \mathrm{M})$ electrode were used as working, counter and reference electrodes respectively. The solutions were sparged with argon before voltammograms were collected. The scan rate was $100 \mathrm{mV} \mathrm{s}^{-1}$ in the positive direction unless otherwise stated.

Spectroelectrochemical measurements were recorded on an Agilent 8453 UV-visible spectrophotometer. The solutions were placed in a custom optically transparent thin layer electrochemical (OTTLE) cell constructed from a Specac Omni-Cell fitted with a platinum mesh working electrode, platinum wire counter electrode and silver wire reference electrode. The solutions contained $0.1 \mathrm{M}$ phosphate buffer $(\mathrm{pH} 7)$ as the supporting electrolyte. The solutions were sparged with argon before being placed in the cell. UV-Vis spectra were collected at $0.05 \mathrm{~V}$ intervals. The time taken between each scan was approximately $10 \mathrm{~s}$.

Photocatalysis reactions were carried out in custom photoreactors where sample vials are placed directly on top of a $455 \mathrm{~nm}$ LED. The sample holder is fitted with cooling water. 


\section{S2. Synthesis}

\section{S2.1 Purification of Q[10]}

$\mathrm{Q}[10]$ was isolated in two steps following a modified literature procedure. ${ }^{1}$ A solid mixture of Q[5], Q[8] and $\mathrm{Q}[5] \subset \mathrm{Q}[10]$, previously synthesized according to a reported procedure ${ }^{2}$ (5.00 g, containing $1.55 \mathrm{mmol}$ $\mathrm{Q}[10])$, was suspended in a mixture of aqueous formic acid $(50 \mathrm{~mL}, 50 \%)$ containing $\mathrm{HCl}(0.5 \mathrm{M}) .1,12-$ Diaminododecane $(2.05 \mathrm{~g}, 10.3 \mathrm{mmol})$ was added and the mixture was heated at reflux for $2 \mathrm{~h}$. The mixture was filtered hot and the solid was washed with hot methanol $(2 \times 25 \mathrm{~mL})$ then dried. The process was repeated until the solid no longer contained any $\mathrm{Q}[5] \subset \mathrm{Q}[10]$ by ${ }^{1} \mathrm{H} N \mathrm{NMR}$, giving 1,12diaminododecane $\cdot \mathrm{HCl} \cdot \mathrm{Q}[10]$ as a colorless powder $(0.895 \mathrm{~g}, 0.472 \mathrm{mmol}, 30 \%)$.

1,12-Diaminododecane $\cdot \mathrm{HCl} \cdot \mathrm{Q}[10](895 \mathrm{mg}, 0.472 \mathrm{mmol})$ was suspended in a solution of $\mathrm{NaOH}$ in methanol $(2 \mathrm{M}, 20 \mathrm{~mL}$ ) and the mixture was heated at reflux for $30 \mathrm{~min}$. It was filtered hot and the solid was washed with methanol $(3 \times 10 \mathrm{~mL})$ then dried to give Q[10] as a colorless powder (342 $\mathrm{mg}, 0.206 \mathrm{mmol}, 44 \%)$.

\section{S2.2 Synthesis of heteroleptic complexes}

[Ru(bpy $\left.)_{2} \mathrm{Cl}_{2}\right](96 \mathrm{mg}, 0.20 \mathrm{mmol})$ and either bpm or bpz $(35 \mathrm{mg}, 0.22 \mathrm{mmol})$ were suspended in water (12 $\mathrm{mL}$ ) and the reaction mixture was heated at reflux under $\mathrm{N}_{2}$ for $24 \mathrm{~h}$. After being cooled to room temperature, any remaining solid was filtered off and the solvent was reduced to approx. $2 \mathrm{~mL}$. THF ( 20 mL) was added to precipitate the complex, which was collected on Celite, washed with THF (5 mL) and redissolved in water. The solvent was removed to give the pure complexes as red-brown solids.

[Ru(bpy) $\left.)_{2}(\mathbf{b p m})\right] \mathbf{C l}_{2}: 99 \mathrm{mg}, 0.14 \mathrm{mmol}, 72 \% .{ }^{1} \mathrm{H} \mathrm{NMR}\left(400 \mathrm{MHz}, \mathrm{D}_{2} \mathrm{O}\right) \delta 9.09(\mathrm{dd}, J=4.9,2.0 \mathrm{~Hz}, 2 \mathrm{H}$, $\left.\mathrm{H}^{\mathrm{M} 4}\right), 8.62-8.52\left(\mathrm{~m}, 4 \mathrm{H}, \mathrm{H}^{\mathrm{Y} 3+\mathrm{Y} 3}\right), 8.24\left(\mathrm{dd}, J=5.8,2.0 \mathrm{~Hz}, 2 \mathrm{H}, \mathrm{H}^{\mathrm{M} 6}\right), 8.15-8.06\left(\mathrm{~m}, 4 \mathrm{H}, \mathrm{H}^{\mathrm{Y} 4+\mathrm{Y} 4}\right), 7.95(\mathrm{ddd}$, $\left.J=5.7,1.5,0.7 \mathrm{~Hz}, 2 \mathrm{H}, \mathrm{H}^{\mathrm{Y} 6}\right), 7.80\left(\mathrm{ddd}, J=5.6,1.5,0.7 \mathrm{~Hz}, 2 \mathrm{H}, \mathrm{H}^{\mathrm{Y} 6}\right), 7.60\left(\mathrm{dd}, J=5.8,4.8 \mathrm{~Hz}, 2 \mathrm{H}, \mathrm{H}^{\mathrm{M} 5}\right)$, $7.45\left(\mathrm{ddd}, J=7.7,5.6,1.3 \mathrm{~Hz}, 2 \mathrm{H}, \mathrm{H}^{\mathrm{Y} 5}\right), 7.41\left(\mathrm{ddd}, J=7.7,5.7,1.3 \mathrm{~Hz}, 2 \mathrm{H}, \mathrm{H}^{\mathrm{Y} 5}\right)$.

[Ru(bpy) $\left.\mathbf{2}_{\mathbf{2}}(\mathbf{b p z})\right] \mathbf{C l}_{2}: 107 \mathrm{mg}, 0.15 \mathrm{mmol}, 77 \% .{ }^{1} \mathrm{H} \mathrm{NMR}\left(400 \mathrm{MHz}, \mathrm{D}_{2} \mathrm{O}\right) \delta 9.78\left(\mathrm{~d}, J=1.2 \mathrm{~Hz}, 2 \mathrm{H}, \mathrm{H}^{\mathrm{z} 3}\right)$, $8.59\left(\mathrm{~d}, J=8.3 \mathrm{~Hz}, 4 \mathrm{H}, \mathrm{H}^{\mathrm{Y} 3+\mathrm{Y} 3^{\prime}}\right), 8.53\left(\mathrm{~d}, J=3.4 \mathrm{~Hz}, 2 \mathrm{H}, \mathrm{H}^{\mathrm{Z} 6}\right), 8.14\left(\mathrm{td}, J=7.9,1.5 \mathrm{~Hz}, 4 \mathrm{H}, \mathrm{H}^{\mathrm{Y} 4+\mathrm{Y} 4}\right), 8.10(\mathrm{dd}$, $\left.J=3.4,1.2 \mathrm{~Hz}, 2 \mathrm{H}, \mathrm{H}^{\mathrm{Z} 5}\right), 7.78\left(\mathrm{ddd}, J=5.6,1.5,0.7 \mathrm{~Hz}, 2 \mathrm{H}, \mathrm{H}^{\mathrm{Y} 6}\right), 7.74\left(\mathrm{ddd}, J=5.6,1.5,0.7 \mathrm{~Hz}, 2 \mathrm{H}, \mathrm{H}^{\mathrm{Y} 6}\right)$, $7.48-7.41\left(\mathrm{~m}, 4 \mathrm{H}, \mathrm{H}^{\mathrm{Y} 5+\mathrm{Y} 5}\right)$. 


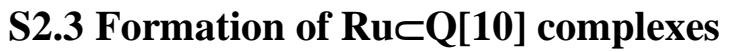

\section{S2.3.1 For NMR experiments}

Excess solid $\mathrm{Q}[10]$ was added to a solution of each complex in $\mathrm{D}_{2} \mathrm{O}$ at $\sim 1 \mathrm{mM}$. After thorough mixing, the remaining solid was removed by filtration through a syringe filter or centrifugation to give the 1:1 host-guest species.

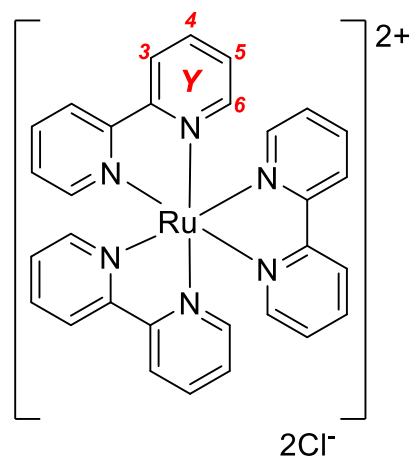

$\left[\mathrm{Ru}(\mathrm{bpy})_{3}\right] \mathrm{Cl}_{2}$

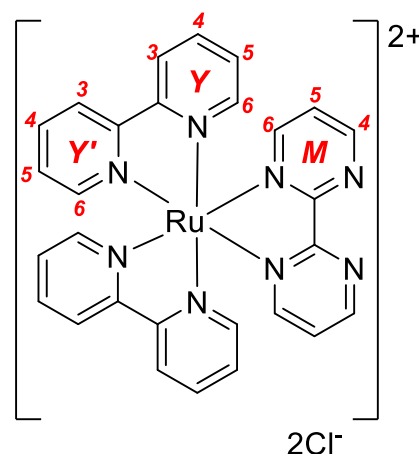

$\left[\mathrm{Ru}(\mathrm{bpy})_{2}(\mathrm{bpm})\right] \mathrm{Cl}_{2}$

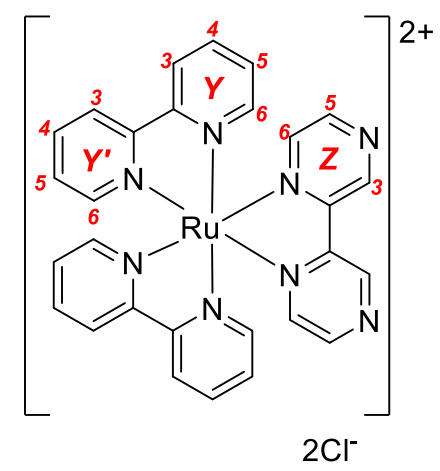

$\left[\mathrm{Ru}(\mathrm{bpy})_{2}(\mathrm{bpz})\right] \mathrm{Cl}_{2}$

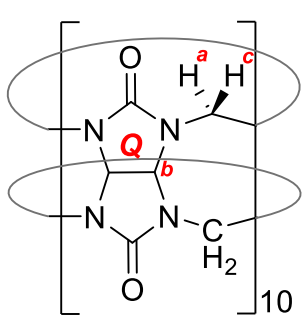

Q[10]

Scheme S1. The complexes used in this study and the numbering scheme adopted.

${ }^{1} \mathrm{H}$ NMR spectra of the host-guest complexes were assigned by 2D NMR techniques in the case of the heteroleptic complexes.

$\left[\mathbf{R u}(\mathbf{b p y})_{3}\right]^{2+} \subset \mathbf{Q}[\mathbf{1 0}]:{ }^{1} \mathrm{H}$ NMR $\left(400 \mathrm{MHz}, \mathrm{D}_{2} \mathrm{O}\right) \delta 8.06\left(\mathrm{~d}, J=8.3 \mathrm{~Hz}, 6 \mathrm{H}, \mathrm{H}^{\mathrm{Y} 3}\right), 7.77\left(\mathrm{t}, J=7.9 \mathrm{~Hz}, 6 \mathrm{H}, \mathrm{H}^{\mathrm{Y} 4}\right)$, $7.41\left(\mathrm{~d}, J=5.6 \mathrm{~Hz}, 6 \mathrm{H}, \mathrm{H}^{\mathrm{Y} 6}\right), 7.26\left(\mathrm{t}, J=6.7 \mathrm{~Hz}, 6 \mathrm{H}, \mathrm{H}^{\mathrm{Y} 5}\right), 5.81\left(\mathrm{~d}, J=15.1 \mathrm{~Hz}, 20 \mathrm{H}, \mathrm{H}^{\mathrm{Q} a}\right), 5.57(\mathrm{~s}, 20 \mathrm{H}$, $\left.\mathrm{H}^{\mathrm{Qb}}\right), 4.25\left(\mathrm{~d}, J=15.2 \mathrm{~Hz}, 20 \mathrm{H}, \mathrm{H}^{\mathrm{Qc}}\right) .{ }^{13} \mathrm{C}\left\{{ }^{1} \mathrm{H}\right\} \mathrm{NMR}\left(151 \mathrm{MHz}, \mathrm{D}_{2} \mathrm{O}\right) \delta 157.3\left(\mathrm{C}^{\mathrm{Q}-\text { amide }}\right), 156.6\left(\mathrm{C}^{\mathrm{Y} 2}\right), 150.8$ $\left(\mathrm{C}^{\mathrm{Y} 6}\right), 137.2\left(\mathrm{C}^{\mathrm{Y} 4}\right), 127.1\left(\mathrm{C}^{\mathrm{Y} 5}\right), 122.9\left(\mathrm{C}^{\mathrm{Y} 3}\right), 73.1\left(\mathrm{C}^{\mathrm{Qb}}\right), 55.2\left(\mathrm{C}^{\mathrm{Qa}, \mathrm{c}}\right)$. HR-ESI-MS m/z 1115.2963 [M-2Cl] $]^{2+}$ requires 1115.3023 .

$\left[\mathbf{R u}(\mathbf{b p y})_{2}(\mathbf{b p m})\right]^{2+} \subset \mathbf{Q}[\mathbf{1 0}]:{ }^{1} \mathrm{H}$ NMR $\left(400 \mathrm{MHz}, \mathrm{D}_{2} \mathrm{O}\right) \delta 9.15\left(\mathrm{dd}, J=4.9,1.9 \mathrm{~Hz}, 2 \mathrm{H}, \mathrm{H}^{\mathrm{M} 4}\right), 8.04(\mathrm{t}, J=5.3$ $\left.\mathrm{Hz}, 2 \mathrm{H}, \mathrm{H}^{\mathrm{M} 5}\right), 7.93\left(\mathrm{~d}, J=5.5 \mathrm{~Hz}, 2 \mathrm{H}, \mathrm{H}^{\mathrm{Y} 6}\right), 7.83\left(\mathrm{~d}, J=8.2 \mathrm{~Hz}, 2 \mathrm{H}, \mathrm{H}^{\mathrm{Y} 3}\right), 7.79\left(\mathrm{~d}, J=8.1 \mathrm{~Hz}, 2 \mathrm{H}, \mathrm{H}^{\mathrm{Y} 3}\right), 7.77$ $-7.68\left(\mathrm{~m}, 4 \mathrm{H}, \mathrm{H}^{\mathrm{M} 6+\mathrm{Y} 4}\right), 7.54\left(\mathrm{t}, J=7.9 \mathrm{~Hz}, 2 \mathrm{H}, \mathrm{H}^{\mathrm{Y} 4}\right), 7.28\left(\mathrm{t}, J=6.6 \mathrm{~Hz}, 2 \mathrm{H}, \mathrm{H}^{\mathrm{Y} 5}\right), 7.02(\mathrm{~d}, J=5.6 \mathrm{~Hz}, 2 \mathrm{H}$, $\left.\mathrm{H}^{\mathrm{Y} 6^{\prime}}\right), 6.80\left(\mathrm{t}, J=6.6 \mathrm{~Hz}, 2 \mathrm{H}, \mathrm{H}^{\mathrm{Y} 5^{\prime}}\right), 5.81\left(\mathrm{~d}, J=15.1 \mathrm{~Hz}, 20 \mathrm{H}, \mathrm{H}^{\mathrm{Qa}}\right), 5.59\left(\mathrm{~s}, 20 \mathrm{H}, \mathrm{H}^{\mathrm{Qb}}\right), 4.27(\mathrm{~d}, J=15.1 \mathrm{~Hz}$, $\left.20 \mathrm{H}, \mathrm{H}^{\mathrm{Qc}}\right) .{ }^{13} \mathrm{C}\left\{{ }^{1} \mathrm{H}\right\}$ NMR $\left(101 \mathrm{MHz}, \mathrm{D}_{2} \mathrm{O}\right) \delta 162.5\left(\mathrm{C}^{\mathrm{M} 2}\right), 159.7\left(\mathrm{C}^{\mathrm{M} 6}\right), 157.5\left(\mathrm{C}^{\mathrm{M} 4}\right), 157.3\left(\mathrm{C}^{\mathrm{Q}-\text { amide }}\right), 156.8$ $\left(\mathrm{C}^{\mathrm{Y} 2}\right), 156.2\left(\mathrm{C}^{\mathrm{Y} 2^{\prime}}\right), 151.9\left(\mathrm{C}^{\mathrm{Y} 6}\right), 150.4\left(\mathrm{C}^{\mathrm{Y} 6}\right), 137.9\left(\mathrm{C}^{\mathrm{Y} 4+\mathrm{Y} 4^{\prime}}\right), 127.6\left(\mathrm{C}^{\mathrm{Y} 5}\right), 126.4\left(\mathrm{C}^{\mathrm{Y} 5^{\prime}}\right), 125.3\left(\mathrm{C}^{\mathrm{M} 5}\right), 123.2$ $\left(\mathrm{C}^{\mathrm{Y} 3}\right), 122.9\left(\mathrm{C}^{\mathrm{Y} 3^{\prime}}\right), 73.1\left(\mathrm{C}^{\mathrm{Qb}}\right), 55.2\left(\mathrm{C}^{\mathrm{Qa}, \mathrm{c}}\right)$. HR-ESI-MS m/z 1116.2972 [M-2Cl] $]^{2+}$ requires 1116.2975.

$\left[\mathbf{R u}(\mathbf{b p y})_{\mathbf{2}}(\mathbf{b p z})\right]^{2+} \subset \mathbf{Q}[\mathbf{1 0}]:{ }^{1} \mathrm{H} \mathrm{NMR}\left(400 \mathrm{MHz}, \mathrm{D}_{2} \mathrm{O}\right) \delta 9.77\left(\mathrm{~s}, 2 \mathrm{H}, \mathrm{H}^{\mathrm{Z} 3}\right), 8.96\left(\mathrm{~d}, J=3.3 \mathrm{~Hz}, 2 \mathrm{H}, \mathrm{H}^{\mathrm{Z} 6}\right), 7.92$ - $7.80\left(\mathrm{~m}, 4 \mathrm{H}, \mathrm{H}^{\mathrm{Y} 3+\mathrm{Y} 3^{\prime}}\right), 7.79-7.68\left(\mathrm{~m}, 4 \mathrm{H}, \mathrm{H}^{\mathrm{Y} 4+\mathrm{Y} 6}\right), 7.62\left(\mathrm{t}, J=7.8 \mathrm{~Hz}, 2 \mathrm{H}, \mathrm{H}^{\mathrm{Y} 4}\right), 7.58-7.52\left(\mathrm{~m}, 2 \mathrm{H}, \mathrm{H}^{\mathrm{z5}}\right)$, $7.27\left(\mathrm{t}, J=6.7 \mathrm{~Hz}, 2 \mathrm{H}, \mathrm{H}^{\mathrm{Y} 5}\right), 7.01\left(\mathrm{~d}, J=5.6 \mathrm{~Hz}, 2 \mathrm{H}, \mathrm{H}^{\mathrm{Y}}{ }^{\prime}\right), 6.87\left(\mathrm{t}, J=6.6 \mathrm{~Hz}, 2 \mathrm{H}, \mathrm{H}^{\mathrm{Y} 5^{\prime}}\right), 5.81(\mathrm{~d}, J=15.2 \mathrm{~Hz}$, $\left.20 \mathrm{H}, \mathrm{H}^{\mathrm{Qa}}\right), 5.60\left(\mathrm{~s}, 20 \mathrm{H}, \mathrm{H}^{\mathrm{Qb}}\right), 4.27\left(\mathrm{~d}, J=15.1 \mathrm{~Hz}, 20 \mathrm{H}, \mathrm{H}^{\mathrm{Qc}}\right) .{ }^{13} \mathrm{C}\left\{{ }^{1} \mathrm{H}\right\} \mathrm{NMR}\left(101 \mathrm{MHz}, \mathrm{D}_{2} \mathrm{O}\right) \delta 157.4\left(\mathrm{C}^{\mathrm{Q}-}\right.$ amide $), 156.1\left(\mathrm{C}^{\mathrm{Y} 2}\right), 156.0\left(\mathrm{C}^{\mathrm{Y} 2^{\prime}}\right), 151.6\left(\mathrm{C}^{\mathrm{Y} 6+\mathrm{Z} 2}\right), 149.8\left(\mathrm{C}^{\mathrm{Y} 6}\right), 148.5\left(\mathrm{C}^{\mathrm{Z} 6}\right), 146.7\left(\mathrm{C}^{\mathrm{Z} 5}\right), 144.0\left(\mathrm{C}^{\mathrm{Z} 3}\right), 138.6\left(\mathrm{C}^{\mathrm{Y} 4^{\prime}}\right)$ $138.2\left(\mathrm{C}^{\mathrm{Y} 4}\right), 127.7\left(\mathrm{C}^{\mathrm{Y} 5}\right), 126.6\left(\mathrm{C}^{\mathrm{Y} 5^{\prime}}\right), 123.0\left(\mathrm{C}^{\mathrm{Y} 3 / \mathrm{Y} 3^{\prime}}\right), 122.8\left(\mathrm{C}^{\mathrm{Y} 3^{\prime} / \mathrm{Y} 3}\right), 73.1\left(\mathrm{C}^{\mathrm{Qb}}\right), 55.3\left(\mathrm{C}^{\mathrm{Qa}, \mathrm{c}}\right)$. HR-ESI-MS $m / z$ $1116.2971[\mathrm{M}-2 \mathrm{Cl}]^{2+}$ requires 1116.2975 . 


\section{S2.3.2 For photophysical or electrochemical measurements}

A solution of known concentration of $\left[\mathrm{Ru}(\mathrm{bpy})_{3}\right] \mathrm{Cl}_{2},\left[\mathrm{Ru}(\mathrm{bpy})_{2}(\mathrm{bpm}) \mathrm{Cl}_{2}\right.$ or $\left[\mathrm{Ru}(\mathrm{bpy})_{2}(\mathrm{bpz})\right] \mathrm{Cl}_{2}$ in Milli-Q water or phosphate buffer solution $(0.1 \mathrm{M}, \mathrm{pH}$ 7) was prepared and split in two to create a sample of free and of encapsulated complex. Excess solid Q[10] was added to one sample, and the mixture was thoroughly mixed before being centrifuged. The supernatant containing the 1:1 host-guest complex was used for photophysical, electrochemical or spectroelectrochemical studies and compared to the results obtained using the free complex.

\section{S2.4 Screening of substrates for the formation of ternary complexes by ${ }^{1} \mathrm{H}$ NMR spectroscopy}

A solution of $\left[\mathrm{Ru}(\mathrm{bpy})_{3}\right] \mathrm{Cl}_{2} \subset \mathrm{Q}[10]$ in $\mathrm{D}_{2} \mathrm{O}(0.6 \mathrm{~mL}, 3 \mathrm{mM})$ was added to one equivalent of each of the substrates, and the ${ }^{1} \mathrm{H}$ NMR spectrum of the sample was recorded. To accurately measure the small amount of substrate required in each NMR sample, a stock solution $(1 \mathrm{~mL}, 30 \mathrm{mM})$ was made up in acetone or water. An aliquot $(100 \mu \mathrm{L})$ of the stock solution was dried, after which the $\left[\mathrm{Ru}(\mathrm{bpy})_{3}\right] \mathrm{Cl}_{2} \subset \mathrm{Q}[10]$ solution was added. For the liquid substrates, the stock solution was made up in $\mathrm{D}_{2} \mathrm{O}(100 \mu \mathrm{L})$ and the aliquot was directly added to the $\left[\mathrm{Ru}(\mathrm{bpy})_{3}\right] \mathrm{Cl}_{2} \subset \mathrm{Q}[10]$ sample. 


\section{S3. ${ }^{1} \mathrm{H}$ NMR spectroscopy data}

\section{S3.1 Encapsulation of complexes in Q[10]}

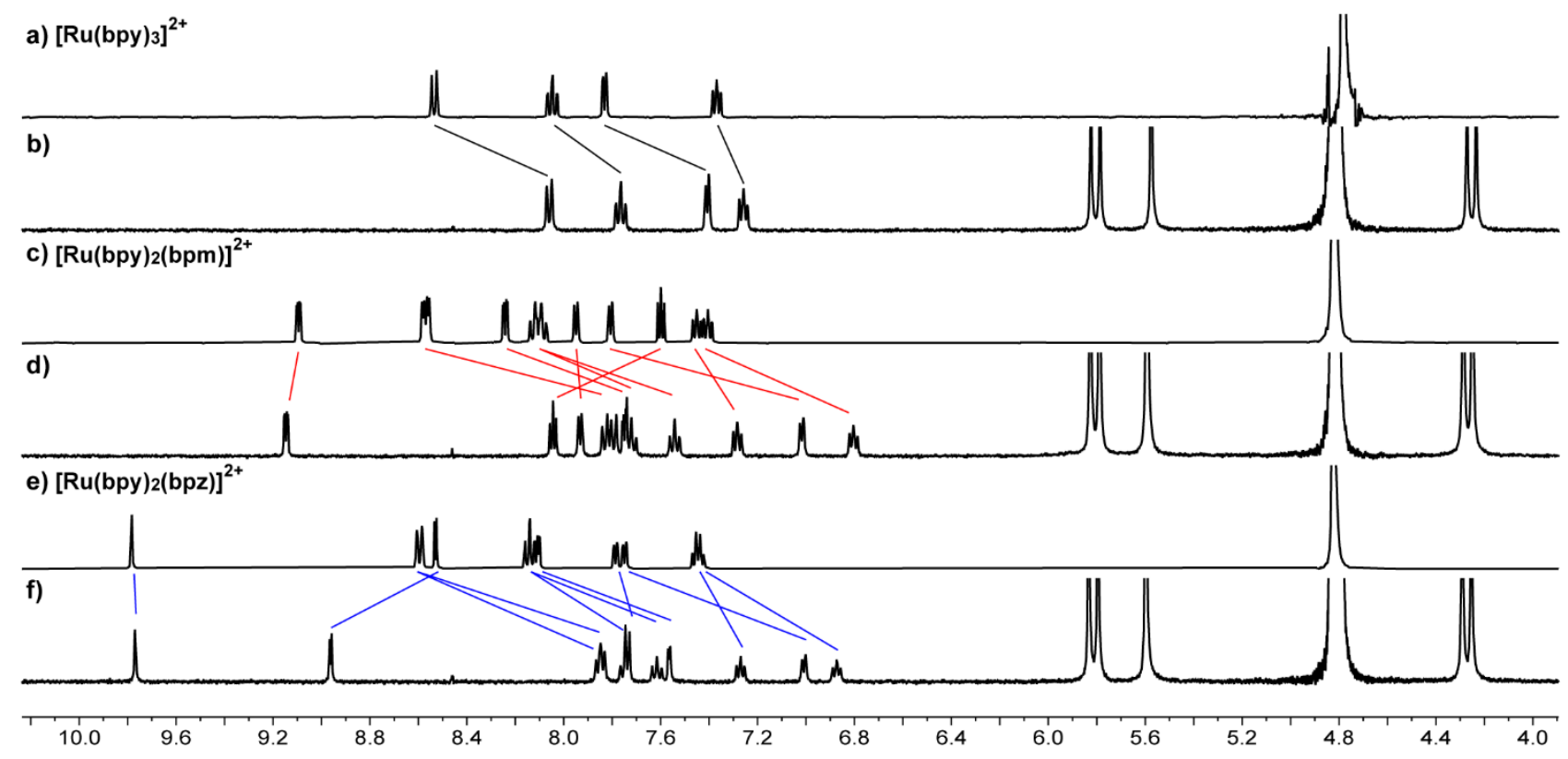

Figure S1. ${ }^{1} \mathrm{H}$ NMR (400 MHz, $\left.\mathrm{D}_{2} \mathrm{O}\right)$ spectra of the complexes in the presence of Q[10]. a-b): $\left[\mathrm{Ru}(\mathrm{bpy})_{3}\right]^{2+}$; c-d): $\left.\left[\mathrm{Ru}(\mathrm{bpy})_{2}(\mathrm{bpm})\right]^{2+} ; \mathrm{e}-\mathrm{f}\right):\left[\mathrm{Ru}(\mathrm{bpy})_{2}(\mathrm{bpz})\right]^{2+}$ 
Table S1. A summary of the changes in the chemical shifts of the signals corresponding to the protons in the complexes studied upon encapsulation, measured by ${ }^{1} \mathrm{H}$ NMR (400 MHz, $\left.\mathrm{D}_{2} \mathrm{O}\right)$.

\begin{tabular}{|c|c|c|c|c|}
\hline Complex & Peak & $\delta$ without Q[10] / ppm & $\delta$ with Q[10] / ppm & $\Delta \delta / \mathrm{ppm}$ \\
\hline \multirow{4}{*}[\mathrm{Ru}(\mathrm{bpy})_{3}]{$\mathrm{Cl}_{2}$} & Y3 & 8.53 & 8.06 & -0.47 \\
\hline & Y4 & 8.05 & 7.77 & -0.28 \\
\hline & Y6 & 7.83 & 7.41 & -0.42 \\
\hline & Y5 & 7.37 & 7.26 & -0.11 \\
\hline \multirow{11}{*}[\mathrm{Ru}(\mathrm{bpy})_{2}(\mathrm{bpm})]{$\mathrm{Cl}_{2}$} & M4 & 9.09 & 9.15 & 0.06 \\
\hline & M6 & 8.24 & 7.75 & -0.49 \\
\hline & M5 & 7.60 & 8.04 & 0.44 \\
\hline & Y3 & 8.57 & 7.83 & -0.74 \\
\hline & Y3' & 8.56 & 7.79 & -0.77 \\
\hline & Y4 & 8.12 & 7.72 & -0.40 \\
\hline & Y4' & 8.09 & 7.54 & -0.55 \\
\hline & Y6 & 7.95 & 7.93 & -0.02 \\
\hline & Y6' & 7.81 & 7.02 & -0.79 \\
\hline & Y5 & 7.45 & 7.28 & -0.17 \\
\hline & Y5' & 7.41 & 6.80 & -0.61 \\
\hline \multirow{11}{*}[\mathrm{Ru}(\mathrm{bpy})_{2}(\mathrm{bpz})]{$\mathrm{Cl}_{2}$} & $\mathrm{Z3}$ & 9.78 & 9.77 & -0.01 \\
\hline & Z6 & 8.53 & 8.96 & 0.43 \\
\hline & $\mathrm{Z} 5$ & 8.10 & 7.56 & -0.54 \\
\hline & $\mathrm{Y} 3$ & 8.60 & 7.86 & -0.74 \\
\hline & Y3' & 8.60 & 7.84 & -0.76 \\
\hline & $\mathrm{Y} 4$ & 8.14 & 7.75 & -0.39 \\
\hline & Y4' & 8.14 & 7.62 & -0.52 \\
\hline & Y6 & 7.79 & 7.74 & -0.05 \\
\hline & Y6' & 7.75 & 7.01 & -0.74 \\
\hline & Y5 & 7.45 & 7.27 & -0.18 \\
\hline & Y5' & 7.44 & 6.87 & -0.57 \\
\hline
\end{tabular}




\section{S3.2 Partial encapsulation with substoichiometric Q[10]}

a)

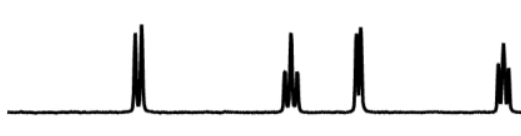

b)

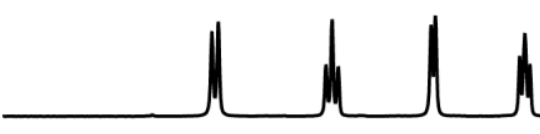

c)

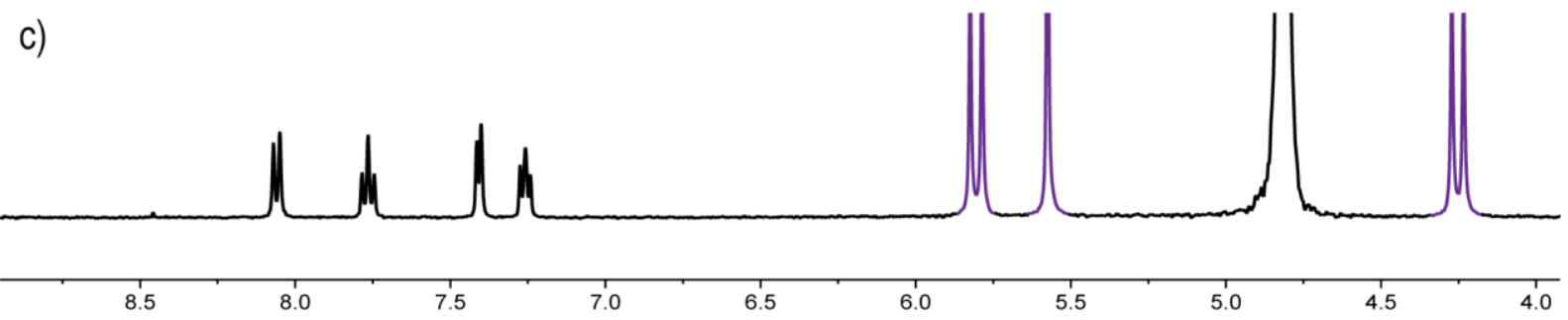

Figure S2. ${ }^{1} \mathrm{H}$ NMR spectra $\left(400 \mathrm{MHz}, \mathrm{D}_{2} \mathrm{O}\right)$ showing the complex is in fast exchange. a) $\left.\left[\mathrm{Ru}(\mathrm{bpy})_{3}\right] \mathrm{Cl}_{2} ; \mathrm{b}\right)$ a $1: 0.5$ mixture of $\left[\mathrm{Ru}(\mathrm{bpy})_{3}\right] \mathrm{Cl}_{2}$ and $\left.\mathrm{Q}[10] ; \mathrm{c}\right)$ a 1:1 mixture of $\left[\mathrm{Ru}(\mathrm{bpy})_{3}\right] \mathrm{Cl}_{2}$ and $\mathrm{Q}[10]$.

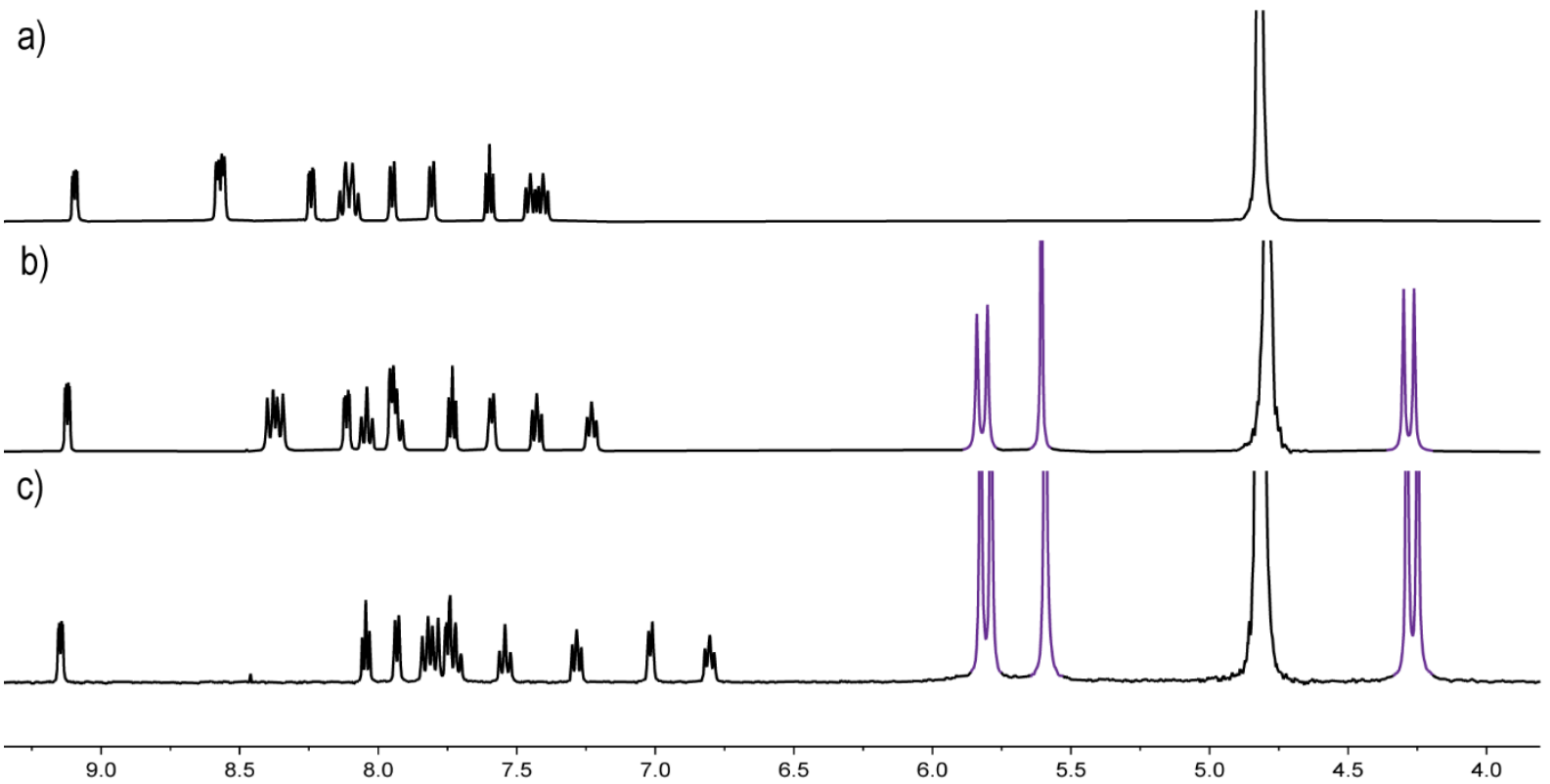

Figure S3. ${ }^{1} \mathrm{H}$ NMR spectra ( $\left.400 \mathrm{MHz}, \mathrm{D}_{2} \mathrm{O}\right)$ showing the complex is in fast exchange. a) $\left.\left[\mathrm{Ru}(\mathrm{bpy})_{2}(\mathrm{bpm})\right] \mathrm{Cl}_{2} ; \mathrm{b}\right)$ a $1: 0.3$ mixture of $\left[\mathrm{Ru}(\mathrm{bpy})_{2}(\mathrm{bpm})\right] \mathrm{Cl}_{2}$ and $\mathrm{Q}[10]$; c) a 1:1 mixture of $\left[\mathrm{Ru}(\mathrm{bpy})_{2}(\mathrm{bpm}) \mathrm{Cl}_{2}\right.$ and $\mathrm{Q}[10]$. 


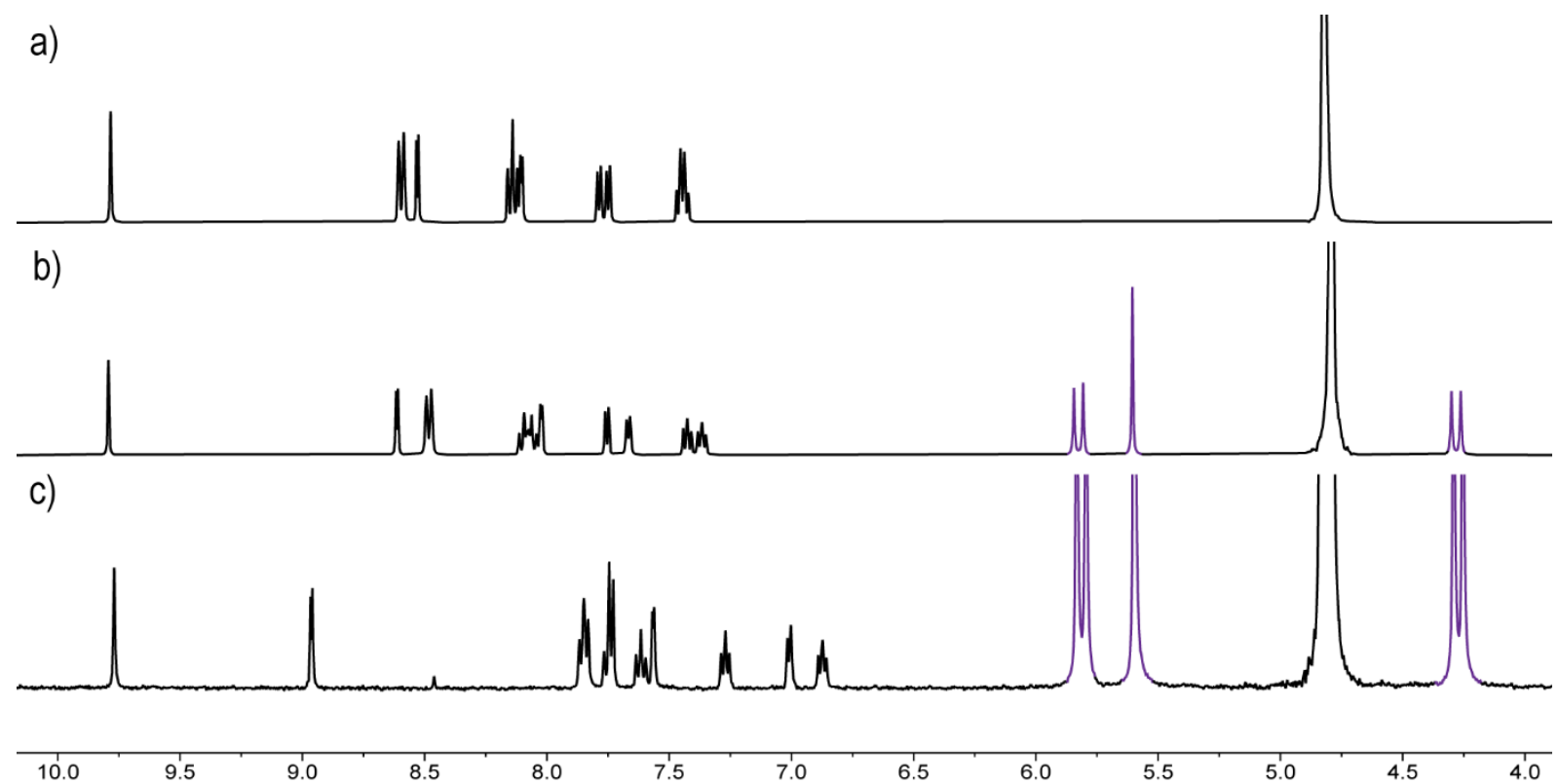

Figure S4. ${ }^{1} \mathrm{H}$ NMR spectra (400 MHz, $\left.\mathrm{D}_{2} \mathrm{O}\right)$ showing the complex is in fast exchange. a) $\left.\left[\mathrm{Ru}(\mathrm{bpy})_{2}(\mathrm{bpz})\right] \mathrm{Cl}_{2} ; \mathrm{b}\right)$ a $1: 0.5$ mixture of $\left[\mathrm{Ru}(\mathrm{bpy})_{2}(\mathrm{bpz})\right] \mathrm{Cl}_{2}$ and $\left.\mathrm{Q}[10] ; \mathrm{c}\right)$ a 1:1 mixture of $\left[\mathrm{Ru}(\mathrm{bpy})_{2}(\mathrm{bpz})\right] \mathrm{Cl}_{2}$ and $\mathrm{Q}[10]$. 


\section{S3.3 Diffusion NMR}

Diffusion measurements were carried out in $\mathrm{D}_{2} \mathrm{O}$ at $400 \mathrm{MHz}$ at $298 \mathrm{~K}$. The pulse program (stebpgp1s19) was a $2 \mathrm{D}$ stimulated echo experiment using bipolar gradients with solvent suppression. For each signal in the ${ }^{1} \mathrm{H}$ NMR spectrum, the diffusion coefficient $(D)$ of the corresponding proton environment was calculated by fitting an exponential curve to a plot of $\mathrm{I} / \mathrm{I}_{0} v s \gamma^{2} \delta^{2}(\Delta-\delta / 3)$ using OriginPro. The error was calculated from standard deviations of the values of $D$ for the different protons in one sample. The hydrodynamic radius was calculated using the Stokes-Einstein equation, $D=\frac{k_{B} T}{6 \pi \eta r_{H}}$.

For $\left[\mathrm{Ru}(\mathrm{bpy})_{3}\right]^{2+} \subset \mathrm{Q}[10]$ in $\mathrm{D}_{2} \mathrm{O}$ at $298 \mathrm{~K}, D=2.65 \pm 0.03 \times 10^{-10} \mathrm{~m}^{-2} \mathrm{~s}^{-2}$ and $r_{\mathrm{H}}=0.8 \mathrm{~nm}$.

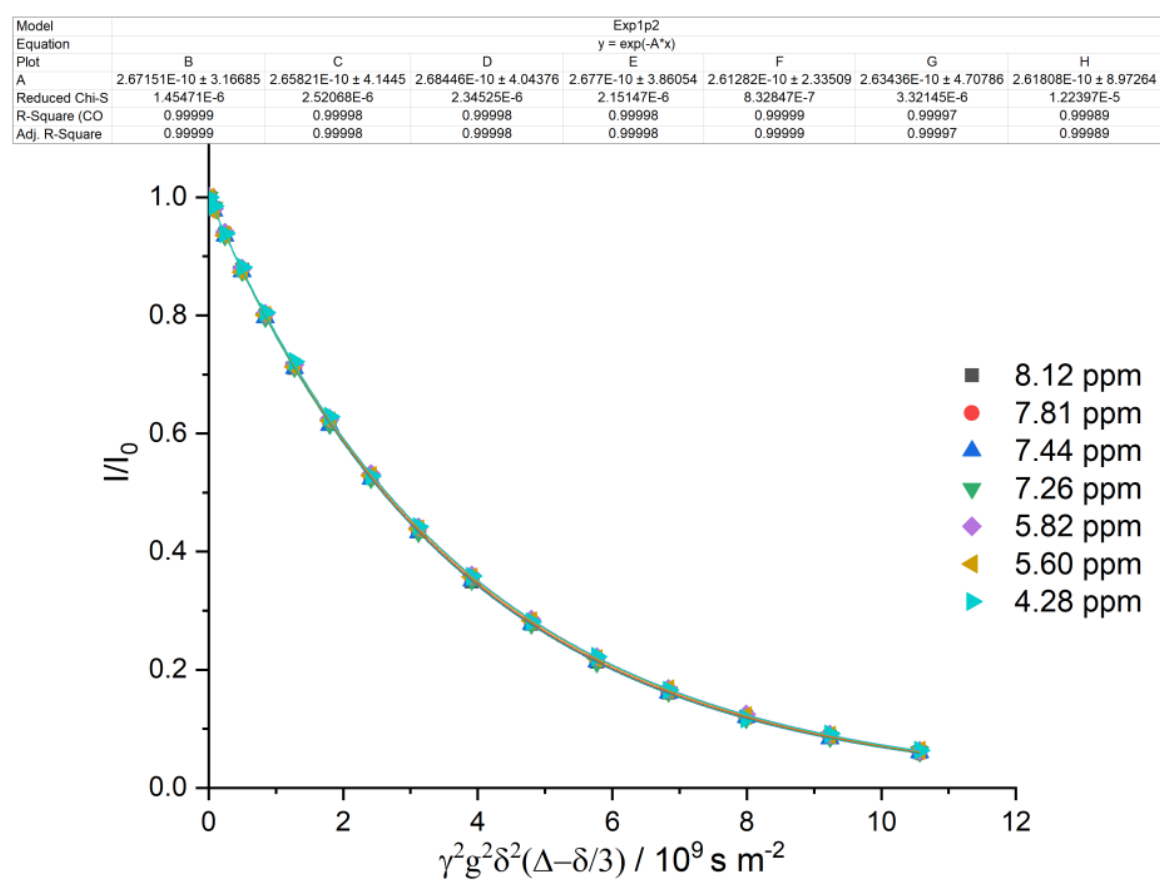

Figure S5. Exponential fit of diffusion parameters for $\left[\mathrm{Ru}(\mathrm{bpy})_{3}\right]^{2+} \subset \mathrm{Q}[10]$ in $\mathrm{D}_{2} \mathrm{O}$ measured by ${ }^{1} \mathrm{H}$ NMR.

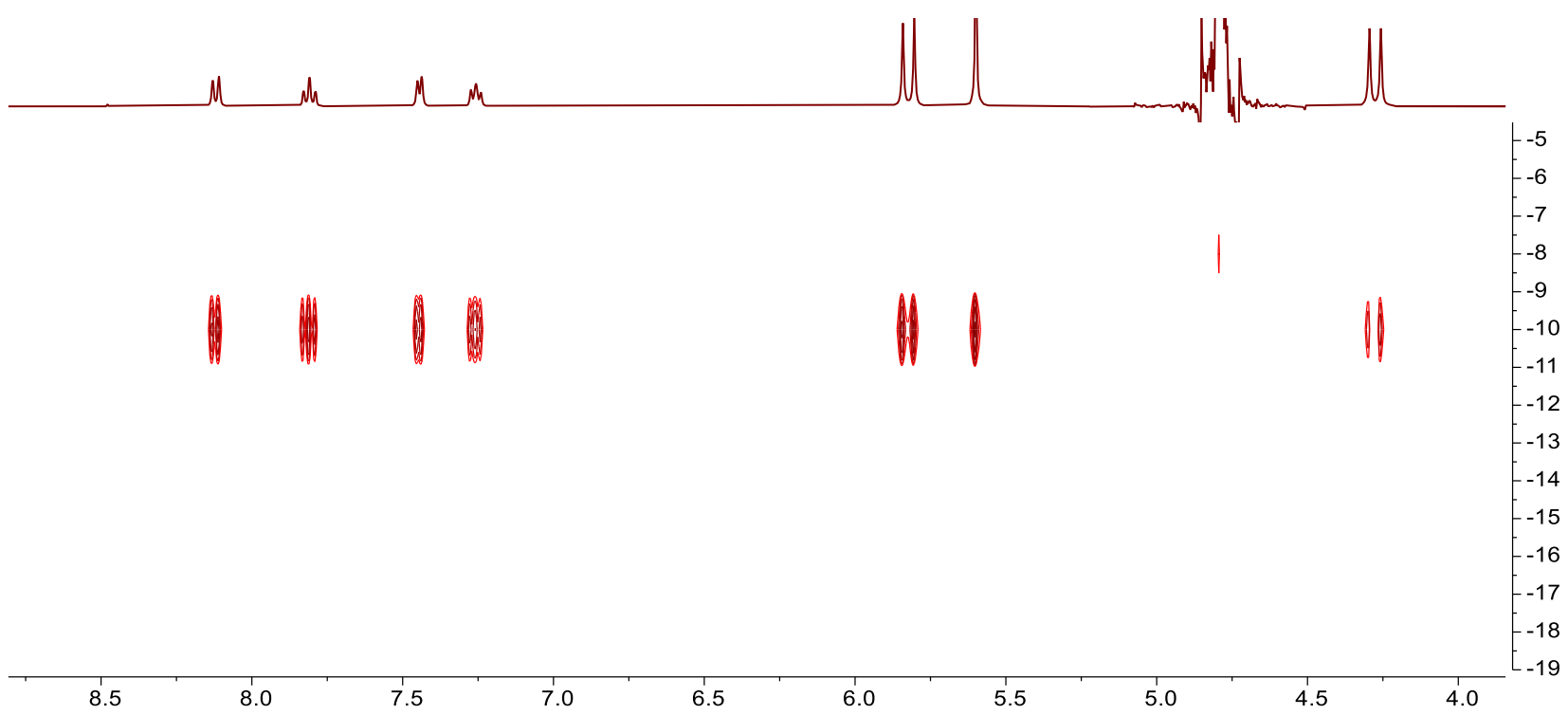

Figure S6. DOSY NMR plot of $\left[\mathrm{Ru}(\mathrm{bpy})_{3}\right]^{2+} \subset \mathrm{Q}[10]\left(400 \mathrm{MHz}, \mathrm{D}_{2} \mathrm{O}\right)$. 
For $\left[\mathrm{Ru}(\mathrm{bpy})_{3}\right]^{2+}$ in $\mathrm{D}_{2} \mathrm{O}$ at $298 \mathrm{~K}, D=3.26 \pm 0.03 \times 10^{-10} \mathrm{~m}^{-2} \mathrm{~s}^{-1}$ and $r_{\mathrm{H}}=0.6 \mathrm{~nm}$.

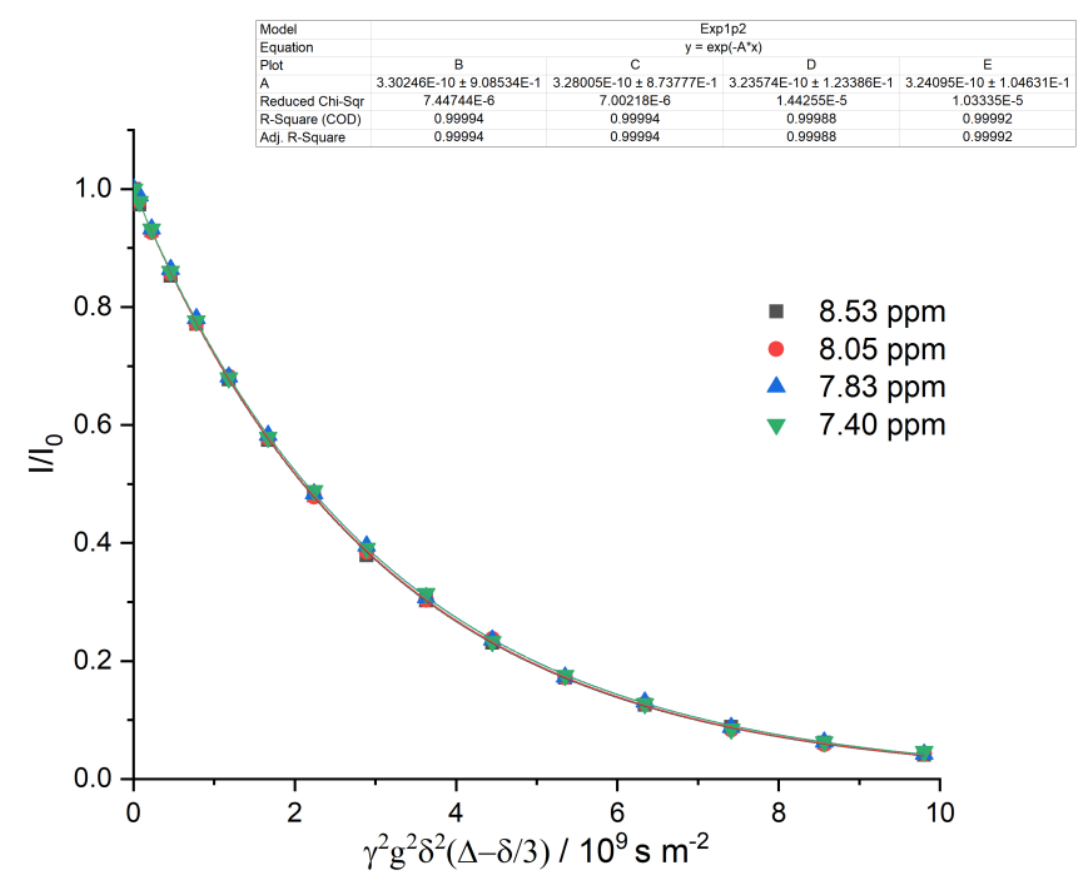

Figure S7. Exponential fit of diffusion parameters for $\left[\mathrm{Ru}(\mathrm{bpy})_{3}\right]^{2+}$ in $\mathrm{D}_{2} \mathrm{O}$ measured by ${ }^{1} \mathrm{H}$ NMR.

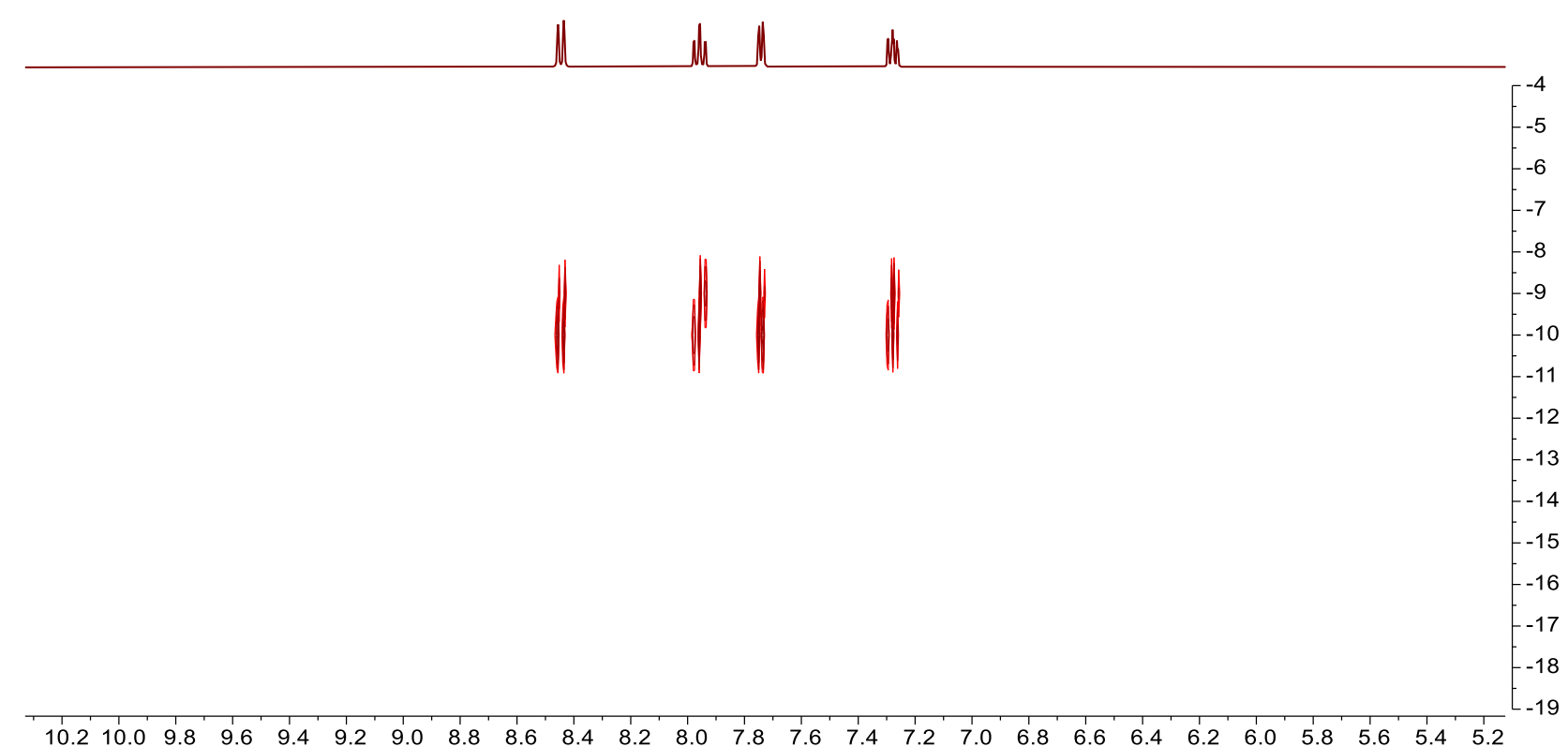

Figure S8. DOSY NMR plot of $\left[\mathrm{Ru}(\mathrm{bpy})_{3}\right]^{2+}\left(400 \mathrm{MHz}, \mathrm{D}_{2} \mathrm{O}\right)$. 
For $\left[\mathrm{Ru}(\mathrm{bpy})_{2}(\mathrm{bpm})\right]^{2+} \subset \mathrm{Q}[10]$ in $\mathrm{D}_{2} \mathrm{O}$ at $298 \mathrm{~K}, D=1.97 \pm 0.11 \times 10^{-10} \mathrm{~m}^{-2} \mathrm{~s}^{-1}$ and $r_{\mathrm{H}}=1.0 \mathrm{~nm}$.

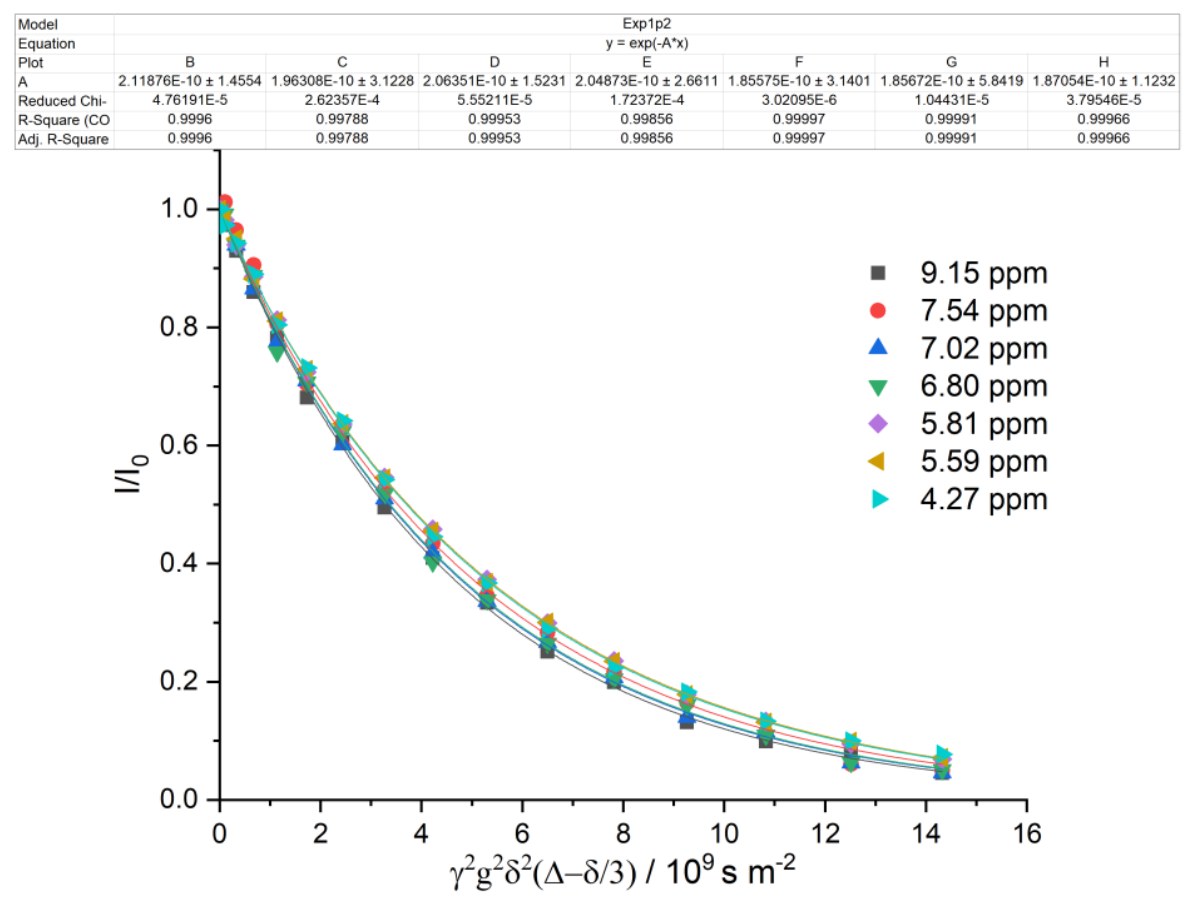

Figure S9. Exponential fit of diffusion parameters for $\left[\mathrm{Ru}(\mathrm{bpy})_{2}(\mathrm{bpm})\right]^{2+} \subset \mathrm{Q}[10]$ in $\mathrm{D}_{2} \mathrm{O}$ measured by ${ }^{1} \mathrm{H}$ NMR.

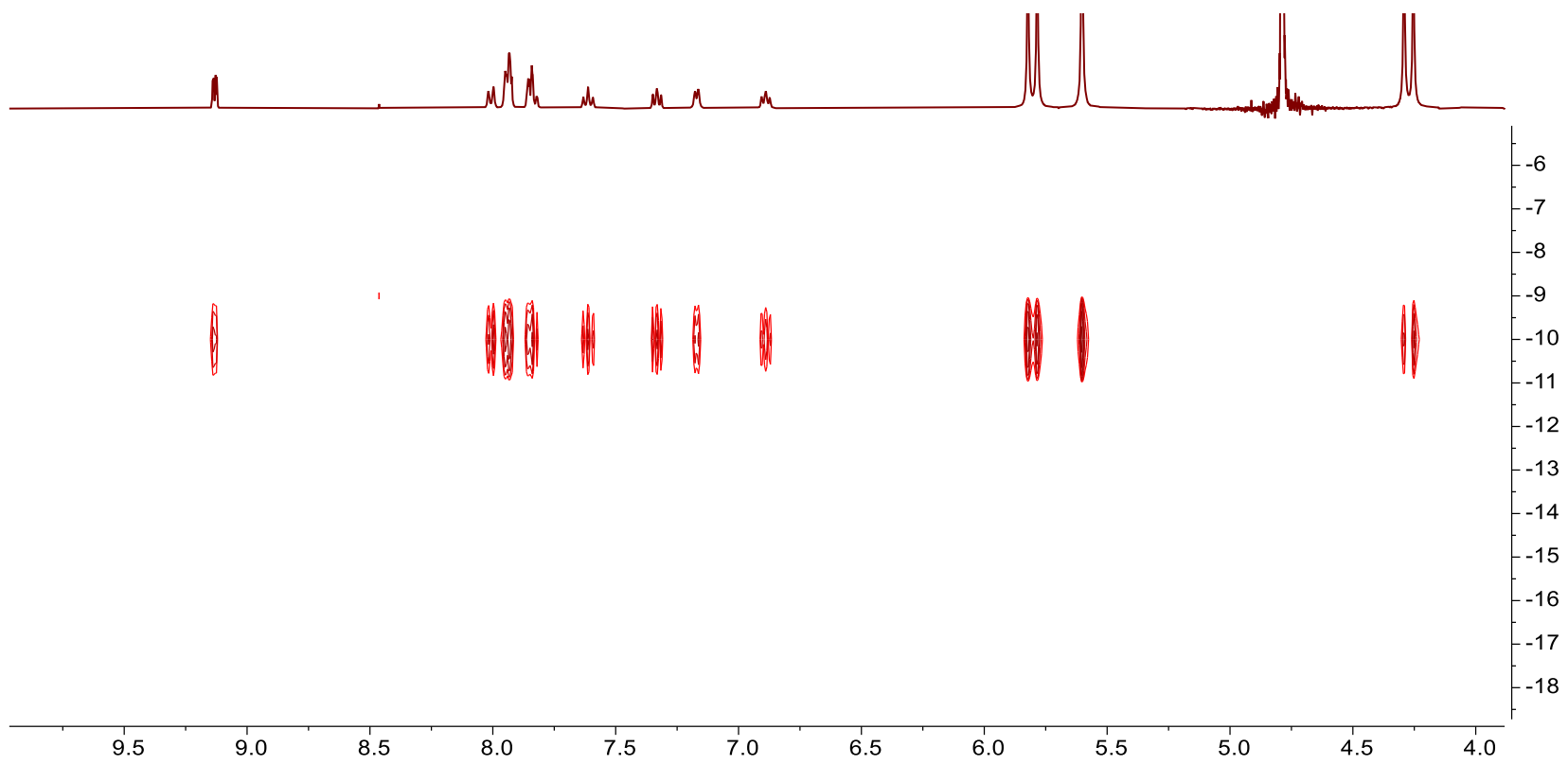

Figure S10. DOSY NMR plot of $\left[\mathrm{Ru}(\mathrm{bpy})_{2}(\mathrm{bpm})\right]^{2+} \subset \mathrm{Q}[10]\left(400 \mathrm{MHz}, \mathrm{D}_{2} \mathrm{O}\right)$. 
For $\left[\mathrm{Ru}(\mathrm{bpy})_{2}(\mathrm{bpm})\right]^{2+}$ in $\mathrm{D}_{2} \mathrm{O}$ at $298 \mathrm{~K}, D=3.23 \pm 0.03 \times 10^{-10} \mathrm{~m}^{-2} \mathrm{~s}^{-1}$ and $r_{\mathrm{H}}=0.6 \mathrm{~nm}$.

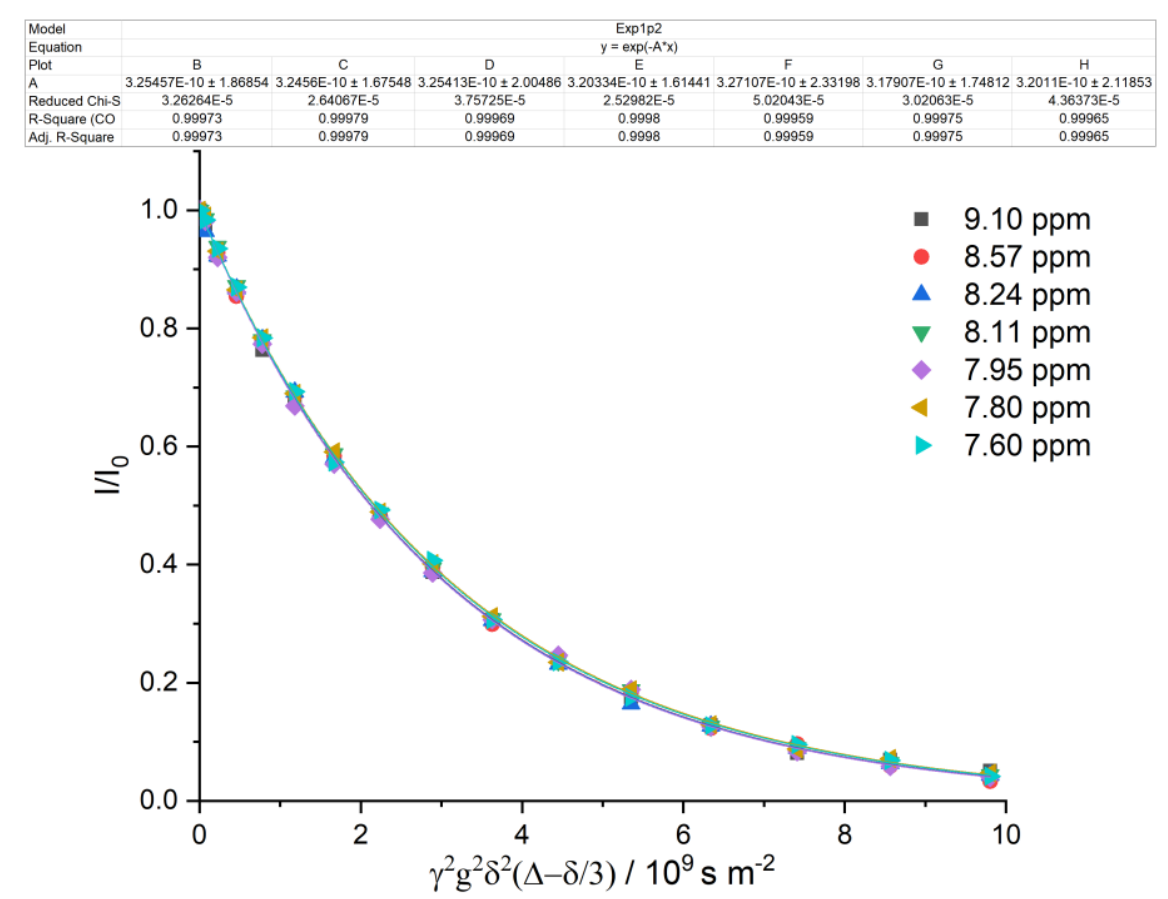

Figure S11. Exponential fit of diffusion parameters for $\left[\mathrm{Ru}(\mathrm{bpy})_{2}(\mathrm{bpm})\right]^{2+}$ in $\mathrm{D}_{2} \mathrm{O}$ measured by ${ }^{1} \mathrm{H}$ NMR.

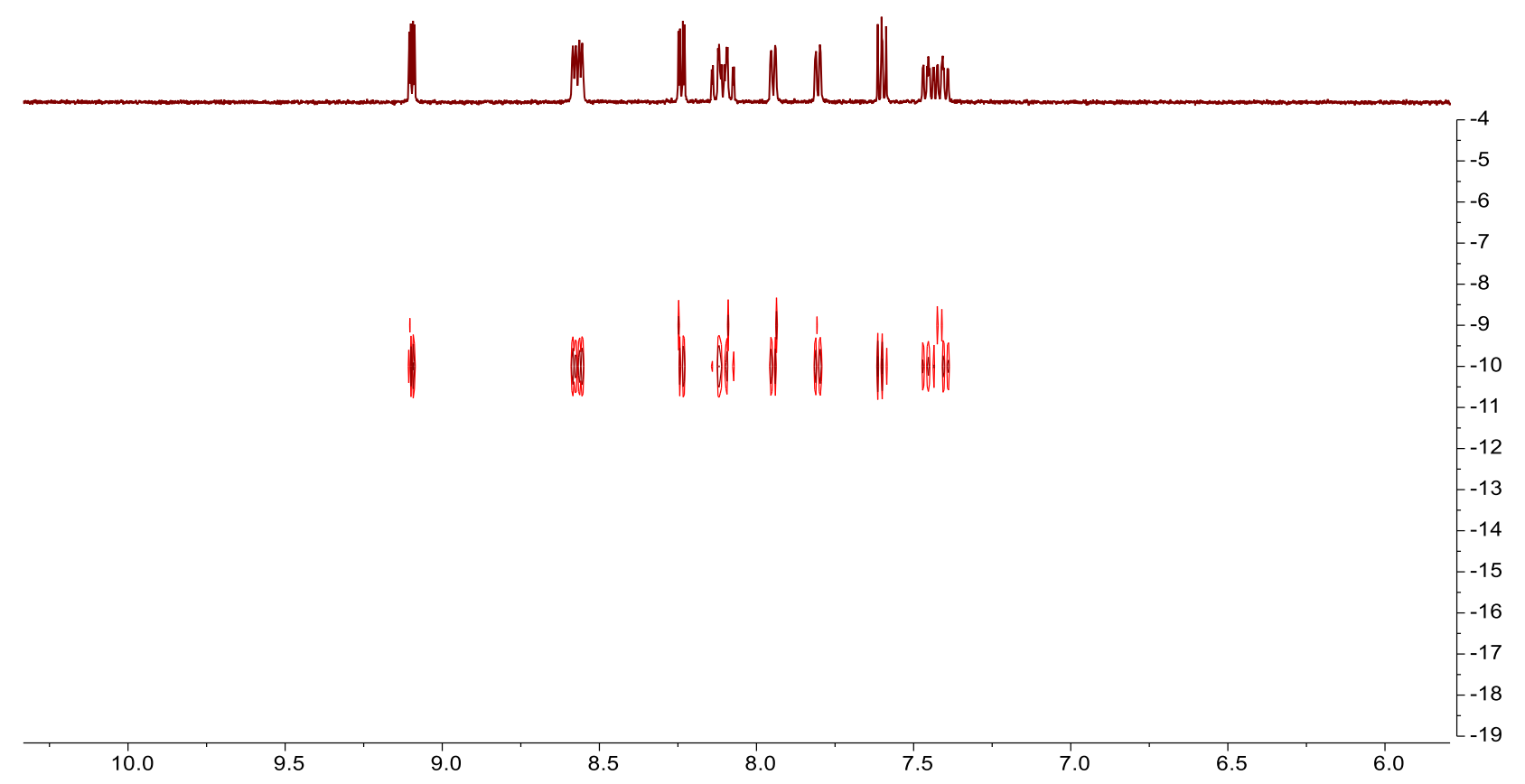

Figure S12. DOSY NMR plot of $\left[\mathrm{Ru}(\mathrm{bpy})_{2}(\mathrm{bpm})\right]^{2+}\left(400 \mathrm{MHz}, \mathrm{D}_{2} \mathrm{O}\right)$. 
For $\left[\mathrm{Ru}(\mathrm{bpy})_{2}(\mathrm{bpz})\right]^{2+} \subset \mathrm{Q}[10]$ in $\mathrm{D}_{2} \mathrm{O}$ at $298 \mathrm{~K}, D=2.09 \pm 0.07 \times 10^{-10} \mathrm{~m}^{-2} \mathrm{~s}^{-1}$ and $r_{\mathrm{H}}=1.0 \mathrm{~nm}$.

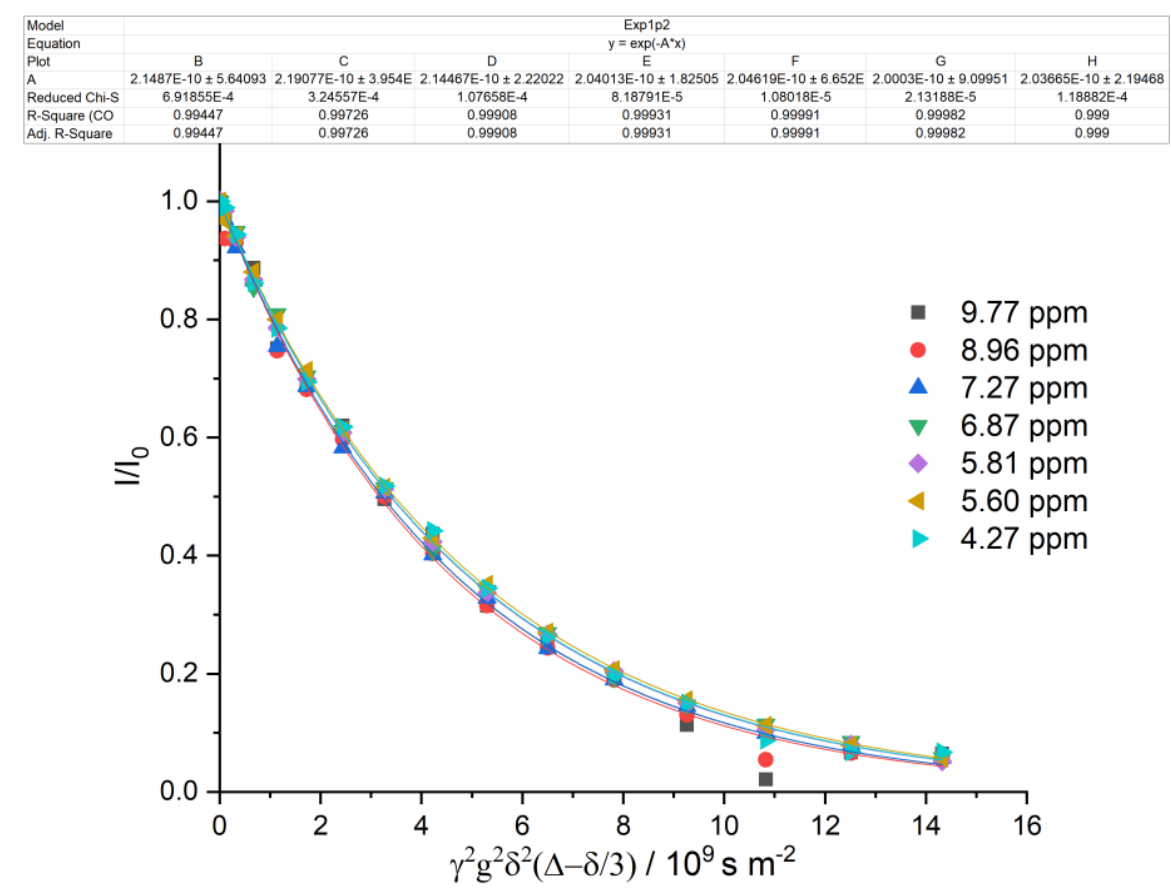

Figure S13. Exponential fit of diffusion parameters for $\left[\mathrm{Ru}(\mathrm{bpy})_{2}(\mathrm{bpz})\right]^{2+} \subset \mathrm{Q}[10]$ in $\mathrm{D}_{2} \mathrm{O}$ measured by ${ }^{1} \mathrm{H} N M R$.

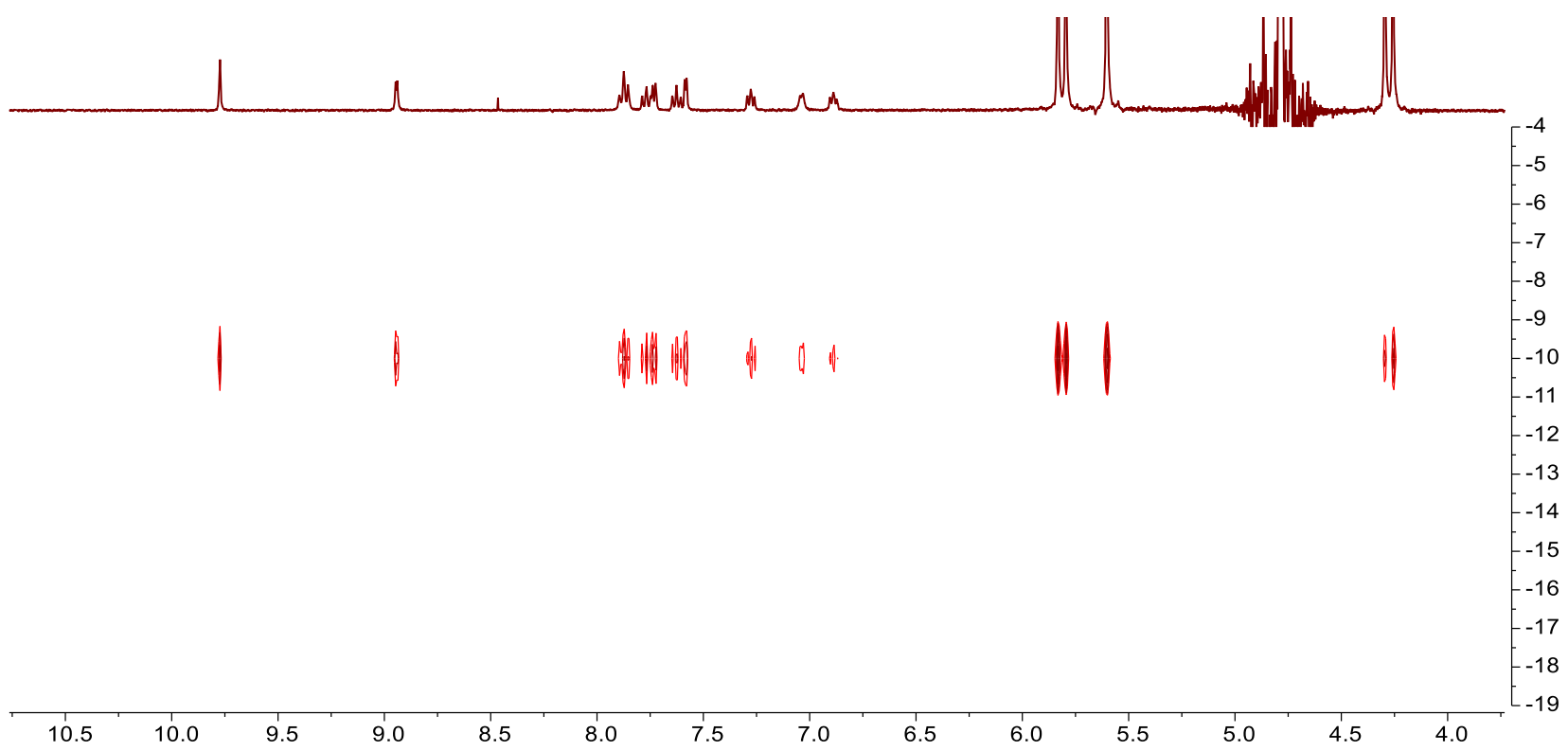

Figure S14. DOSY NMR plot of $\left[\mathrm{Ru}(\mathrm{bpy})_{2}(\mathrm{bpz})\right]^{2+} \subset \mathrm{Q}[10]\left(400 \mathrm{MHz}, \mathrm{D}_{2} \mathrm{O}\right)$. 
For $\left[\mathrm{Ru}(\mathrm{bpy})_{2}(\mathrm{bpz})\right]^{2+}$ in $\mathrm{D}_{2} \mathrm{O}$ at $298 \mathrm{~K}, D=3.27 \pm 0.03 \times 10^{-10} \mathrm{~m}^{-2} \mathrm{~s}^{-1}$ and $r_{\mathrm{H}}=0.6 \mathrm{~nm}$.

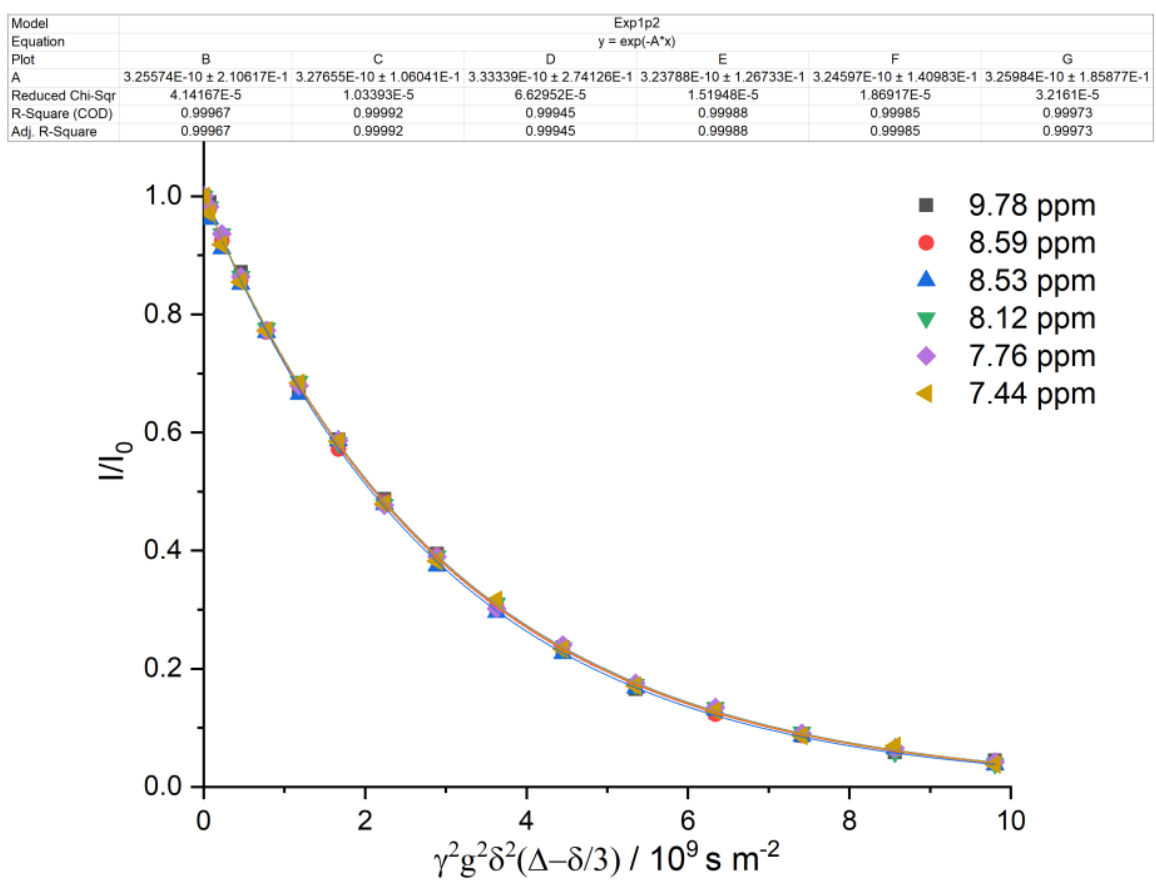

Figure S15. Exponential fit of diffusion parameters for $\left[\mathrm{Ru}(\mathrm{bpy})_{2}(\mathrm{bpz})\right]^{2+}$ in $\mathrm{D}_{2} \mathrm{O}$ measured by ${ }^{1} \mathrm{H}$ NMR.

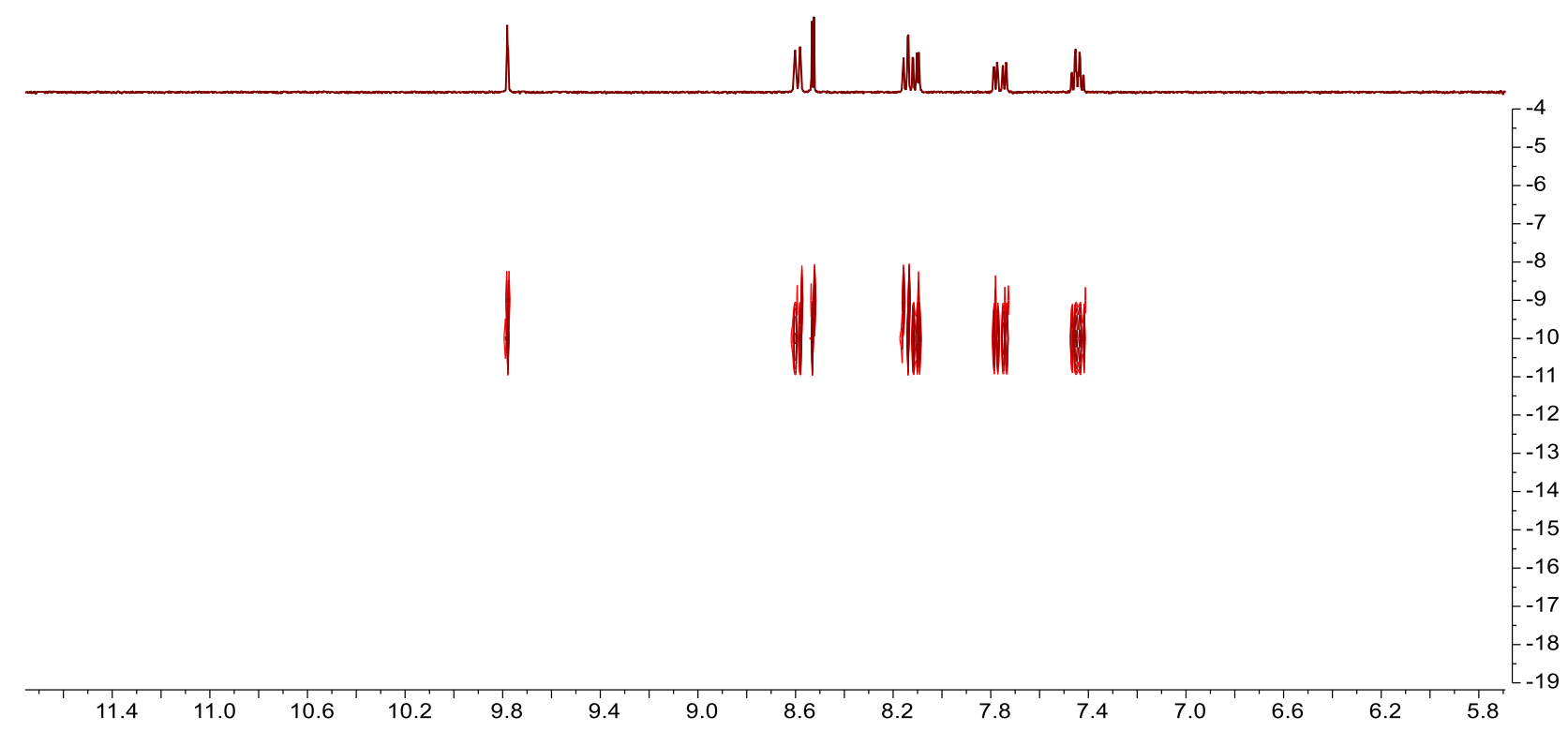

Figure S16. DOSY NMR plot of $\left[\mathrm{Ru}(\mathrm{bpy})_{2}(\mathrm{bpz})\right]^{2+}\left(400 \mathrm{MHz}, \mathrm{D}_{2} \mathrm{O}\right)$. 


\section{S4. HR-ESI-MS data}

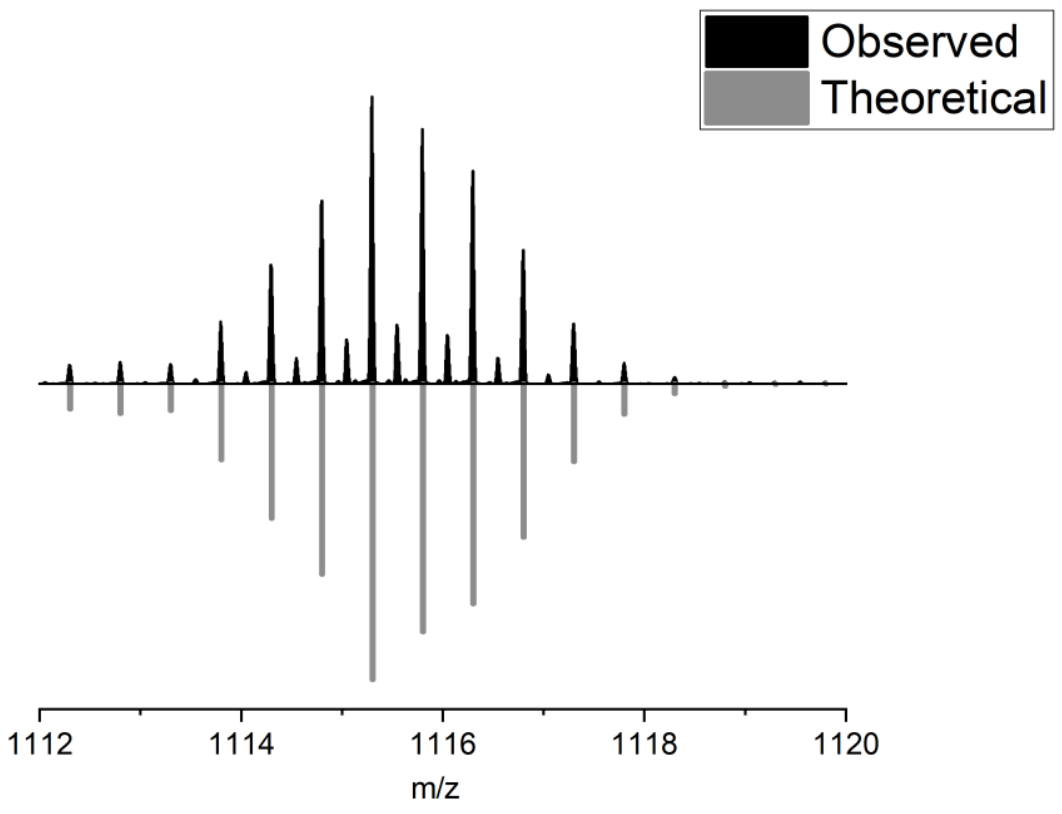

Figure S17. Observed and theoretical isotope pattern observed for $\left[\mathrm{Ru}(\mathrm{bpy})_{3}\right]^{2+} \subset \mathrm{Q}[10]$. The lower intensity signals indicate the presence of a dimer of $\left[\mathrm{Ru}(\mathrm{bpy})_{3}\right]^{2+} \subset \mathrm{Q}[10]$ under these conditions, which was not detected using other characterization methods.

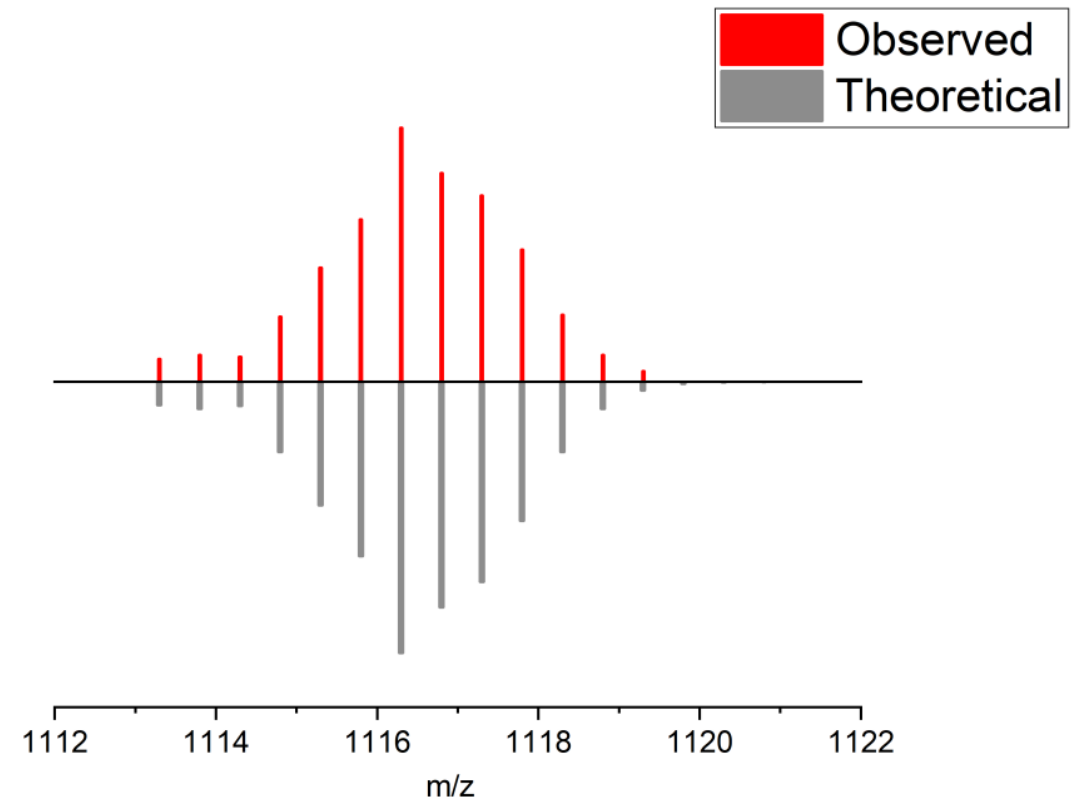

Figure S18. Observed and theoretical isotope pattern observed for $\left[\mathrm{Ru}(\mathrm{bpy})_{2}(\mathrm{bpm})\right]^{2+} \subset \mathrm{Q}[10]$. 


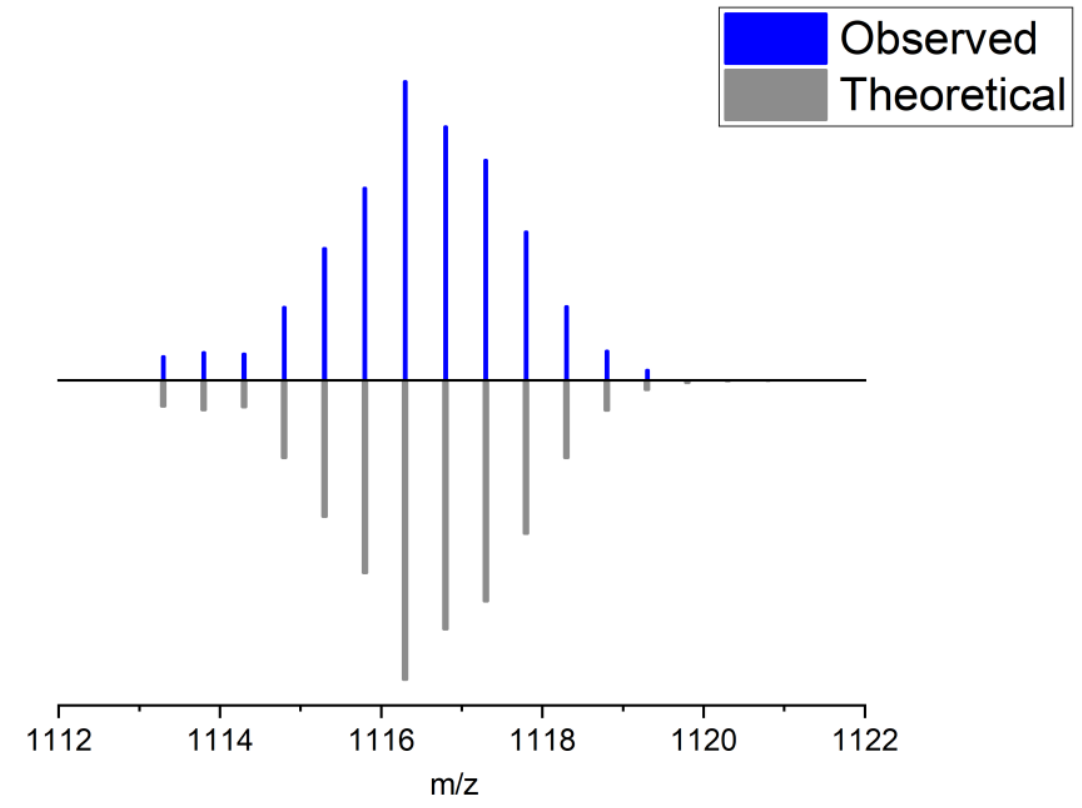

Figure S19. Observed and theoretical isotope pattern observed for $\left[\mathrm{Ru}(\mathrm{bpy})_{2}(\mathrm{bpz})\right]^{2+} \subset \mathrm{Q}[10]$. 


\section{S5. Additional photophysical data}

\section{S5.1 Emission intensity of the encapsulated complexes}

The emission of the encapsulated ruthenium(II) complexes were compared to those of the free forms. This was done for each complex by normalizing the maximum emission intensity to its absorbance at $\lambda_{\mathrm{ex}}$. The maximum emission from each free complex was then set to 1 , and the emission of the corresponding encapsulated complex was scaled accordingly.

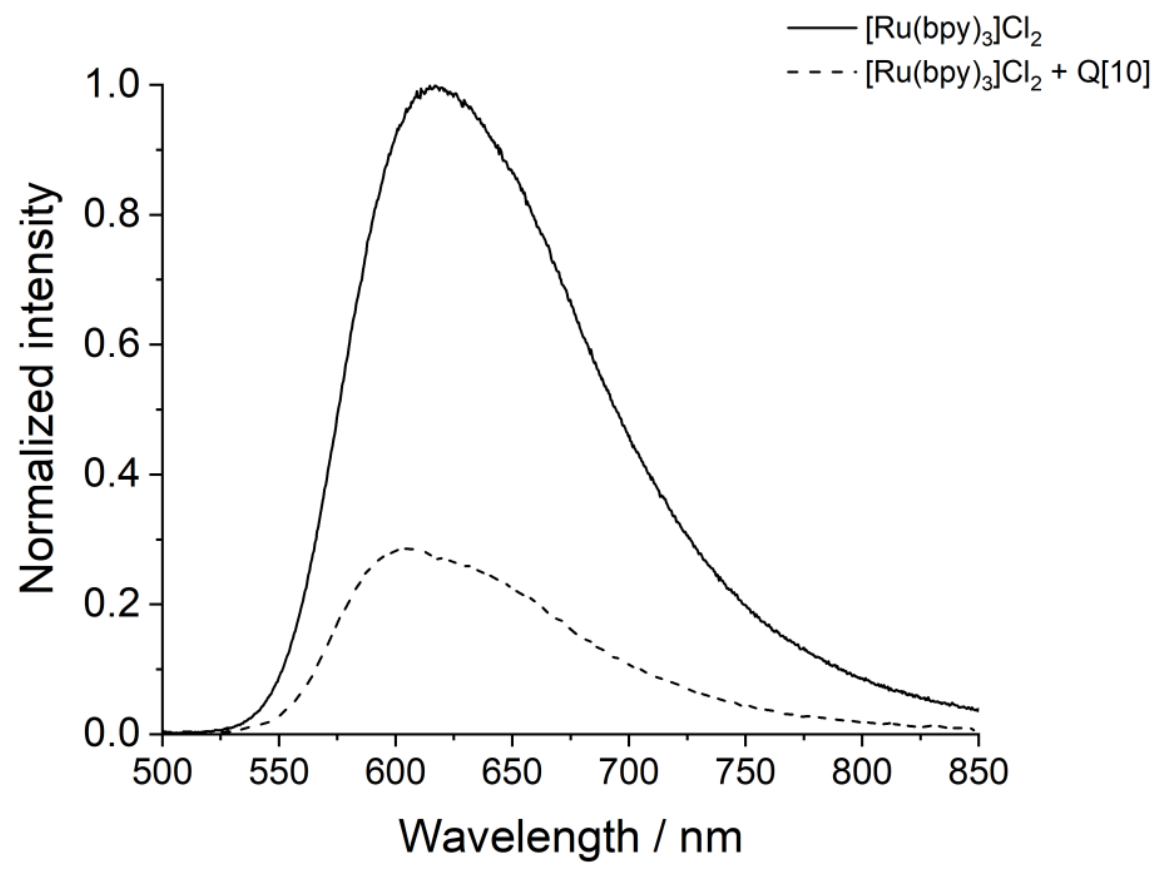

Figure S20. Emission spectra $\left(\mathrm{H}_{2} \mathrm{O}, 298 \mathrm{~K}, 10 \mu \mathrm{M}\right)$ of free and encapsulated $\left[\mathrm{Ru}(\mathrm{bpy})_{3}\right]^{2+}$ normalized to the emission of the free complex. 


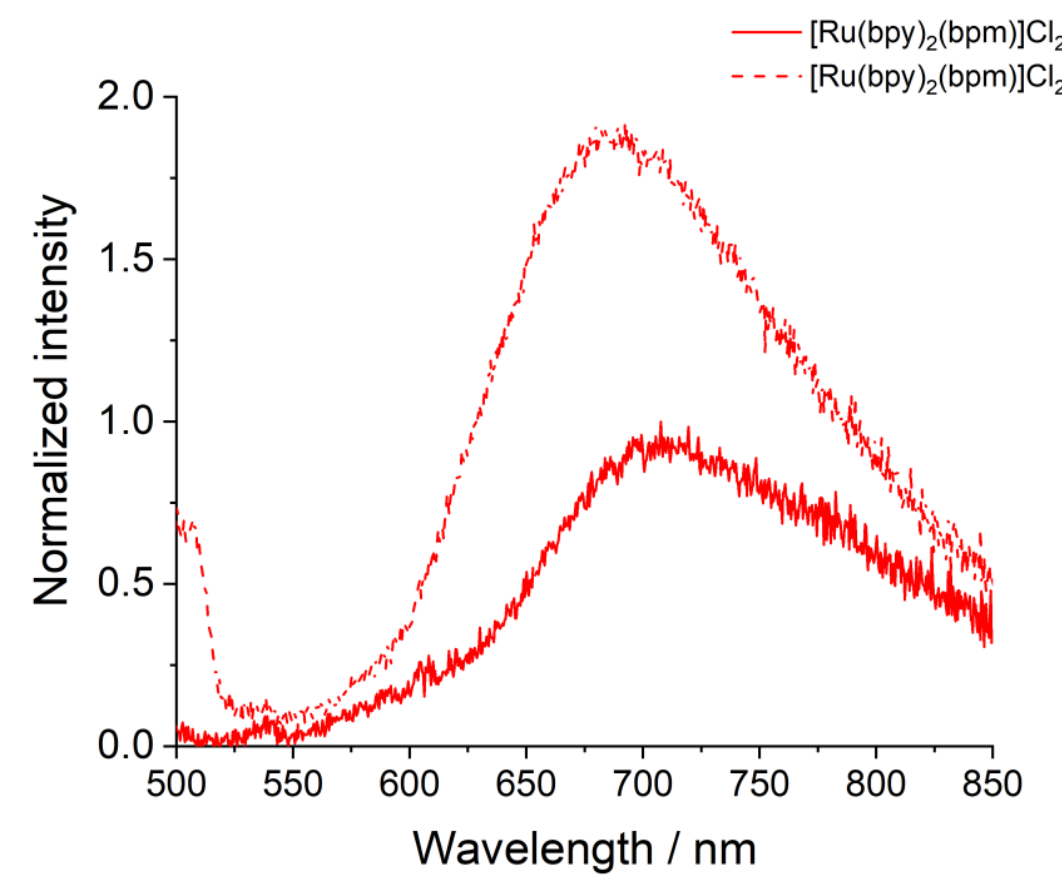

Figure S21. Emission spectra $\left(\mathrm{H}_{2} \mathrm{O}, 298 \mathrm{~K}, 10 \mu \mathrm{M}\right)$ of free and encapsulated $\left[\mathrm{Ru}(\mathrm{bpy})_{2}(\mathrm{bpm})\right]^{2+}$ normalized to the emission of the free complex.

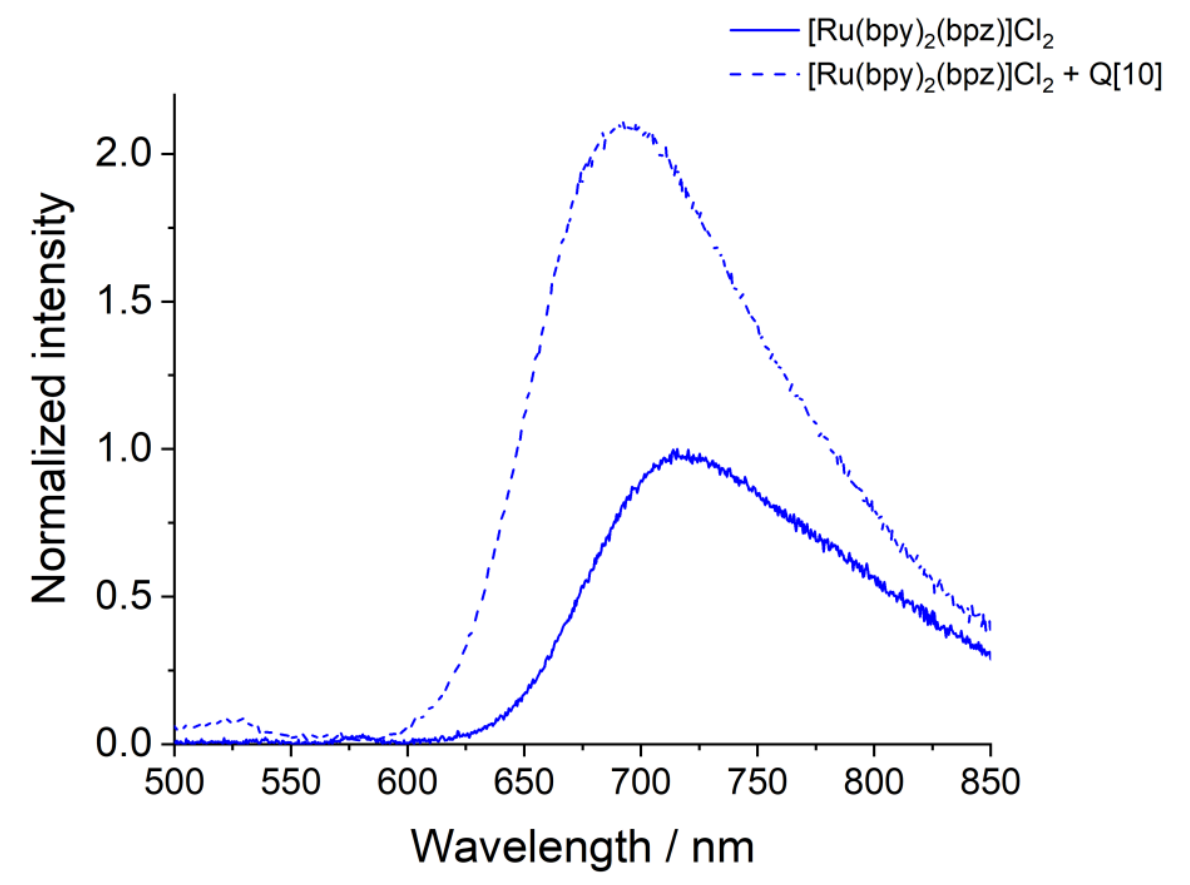

Figure S22. Emission spectra $\left(\mathrm{H}_{2} \mathrm{O}, 298 \mathrm{~K}, 10 \mu \mathrm{M}\right)$ of free and encapsulated $\left[\mathrm{Ru}(\mathrm{bpy})_{2}(\mathrm{bpz})\right]^{2+}$ normalized to the emission of the free complex. 


\section{S5.2 Emission behavior in the presence of added acid or base}

The behavior of the complexes in the presence of acid or base was investigated to determine any effects of encapsulation on the $\mathrm{p} K_{\mathrm{a}}$ of $\left[\mathrm{Ru}(\mathrm{bpy})_{2}(\mathrm{bpm})\right]^{2+}$ and $\left[\mathrm{Ru}(\mathrm{bpy})_{2}(\mathrm{bpz})\right]^{2+}$. The emission of the complexes was monitored because protonated forms of $\left[\mathrm{Ru}(\mathrm{bpy})_{2}(\mathrm{bpm})\right]^{2+}$ and $\left[\mathrm{Ru}(\mathrm{bpy})_{2}(\mathrm{bpz})\right]^{2+}$ are known to be nonemissive. ${ }^{3-4}$ Aliquots of a solution of $\mathrm{HCl}$ or $\mathrm{NaOH}(\sim 23 \mathrm{mM})$ were added to solutions of the free and encapsulated complexes up to a total of 1000 equivalents. $\left[\mathrm{Ru}(\mathrm{bpy})_{3}\right]^{2+}$ was included as a control experiment wherein the emission was not expected to change due to the lack of protonatable sites.

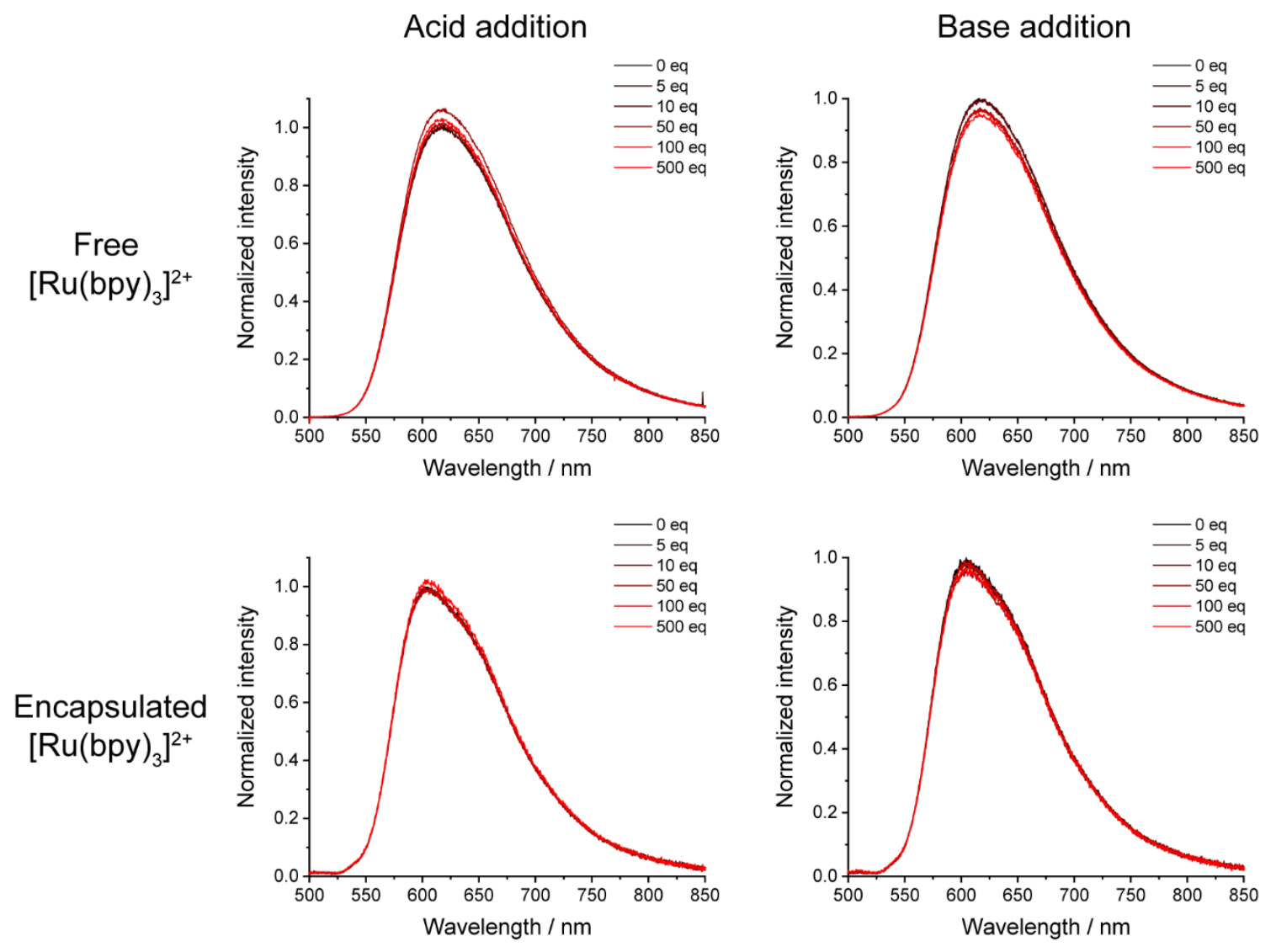

Figure S23. Normalized emission spectra of free and encapsulated $\left[\mathrm{Ru}(\mathrm{bpy})_{3}\right]^{2+}$ in the presence of up to 500 equivalents of acid or base $\left(\mathrm{H}_{2} \mathrm{O}, 298 \mathrm{~K}, 9 \mu \mathrm{M}\right)$. As expected, the emission is unaffected by acid or base. 

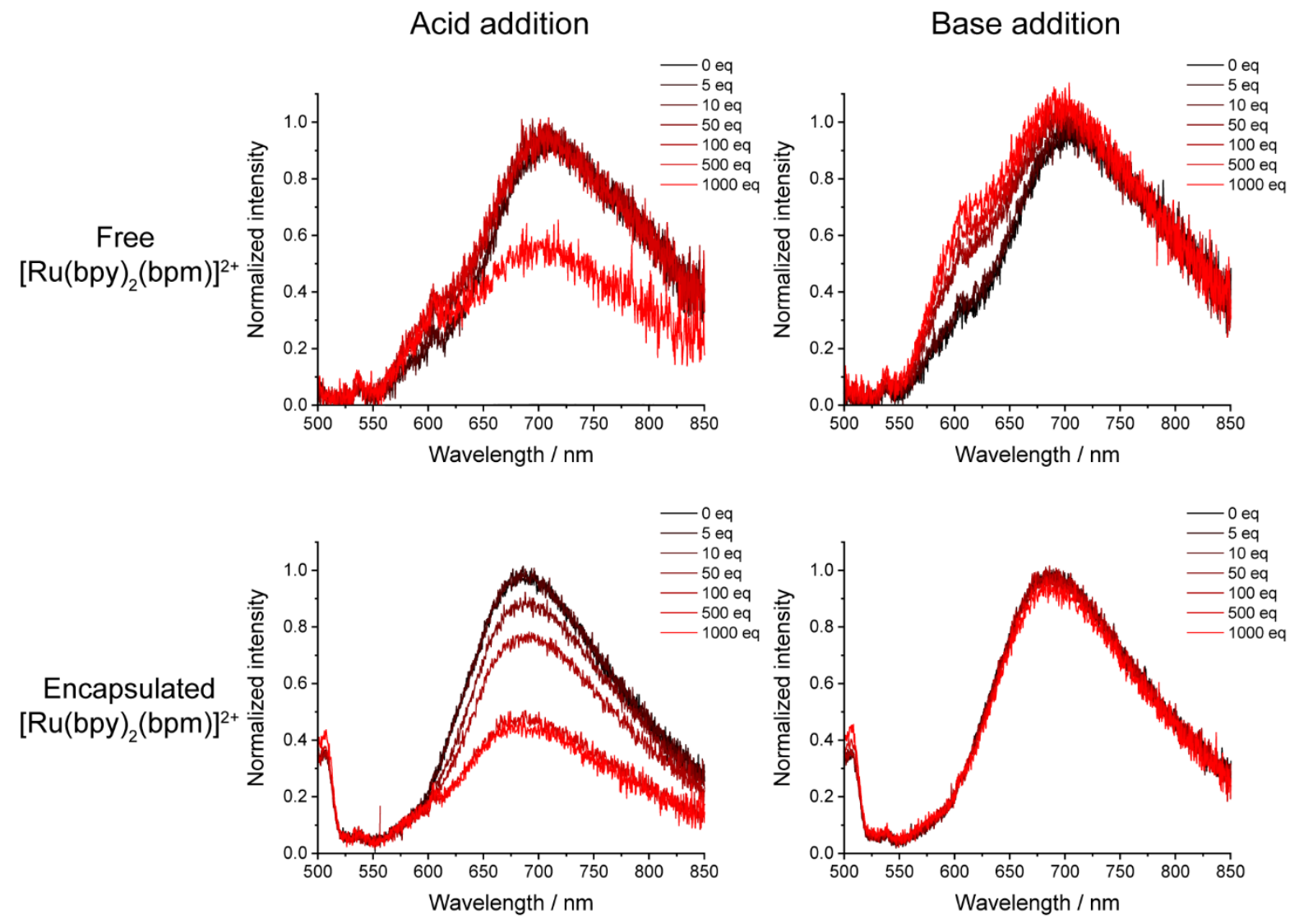

Figure S24. Normalized emission spectra of free and encapsulated $\left[\mathrm{Ru}(\mathrm{bpy})_{3}(\mathrm{bpm})\right]^{2+}$ in the presence of up to 1000 equivalents of acid or base $\left(\mathrm{H}_{2} \mathrm{O}, 298 \mathrm{~K}, 9 \mu \mathrm{M}\right)$. The emission intensity decreases for both the free and encapsulated complexes, resulting from the formation of non-emissive $\left[\mathrm{Ru}(\mathrm{bpy})_{2}(\mathrm{bpmH})\right]^{3+}$. However, the emission of the complex is more susceptible to acid concentration when it is bound, suggesting that encapsulation within Q[10] leads to an increase in the $\mathrm{p} K_{\mathrm{a}}$ of the complex. The addition of acid or base to the free complex leads to an increased emission intensity from a shoulder at $600 \mathrm{~nm}$, which is more pronounced in the presence of base. Emission from this state is prevented when $\left[\mathrm{Ru}(\mathrm{bpy})_{2}(\mathrm{bpm})\right]^{2+}$ is encapsulated. The cause of this emission band remains unclear. 

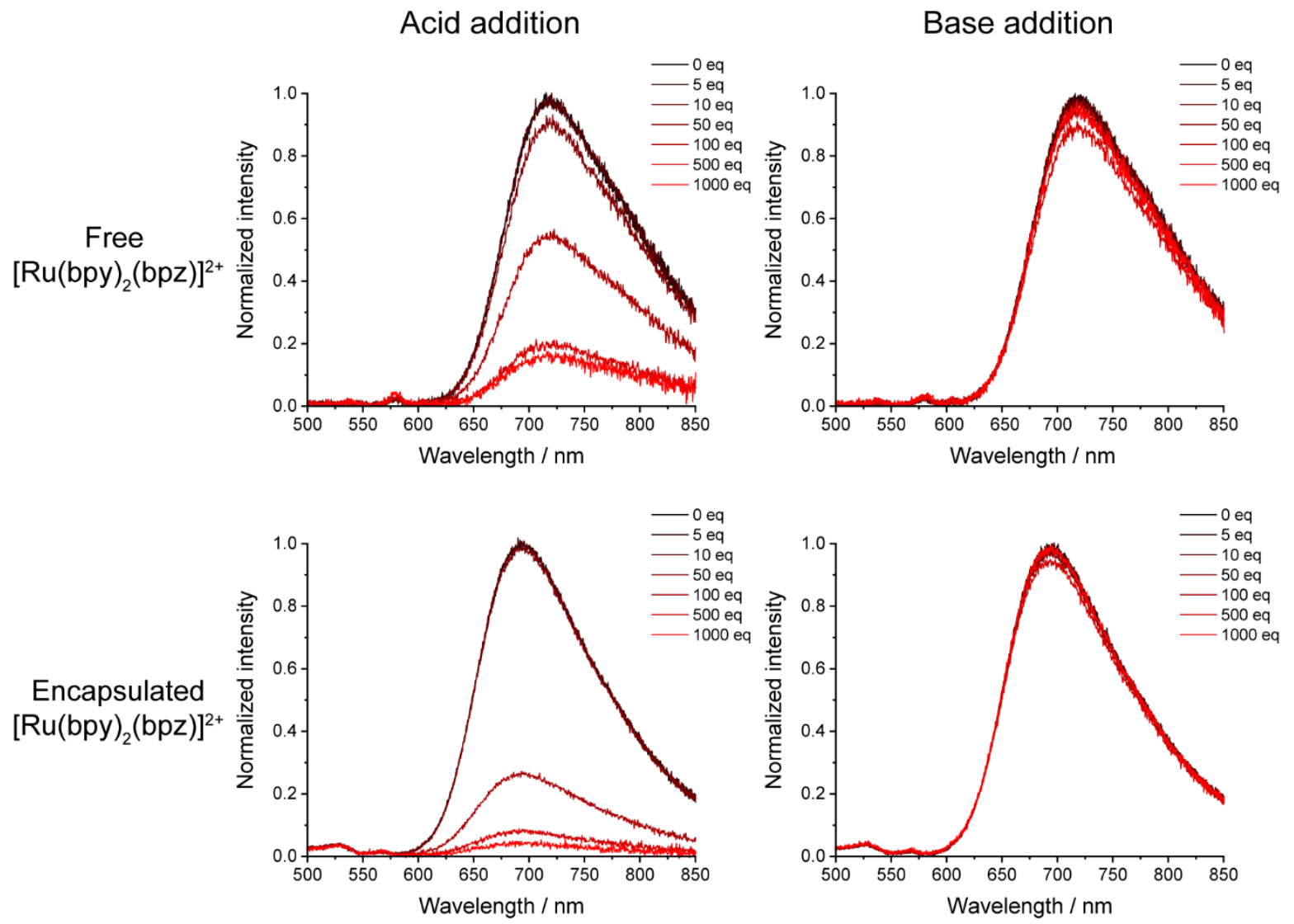

Figure S25. Normalized emission spectra of free and encapsulated $\left[\mathrm{Ru}(\mathrm{bpy})_{2}(\mathrm{bpz})\right]^{2+}$ in the presence of up to 1000 equivalents of acid or base $\left(\mathrm{H}_{2} \mathrm{O}, 298 \mathrm{~K}, 9 \mu \mathrm{M}\right)$. The emission is not significantly affected by added base. Non-emissive $\left[\mathrm{Ru}(\mathrm{bpy})_{2}(\mathrm{bpzH})\right]^{3+}$ forms in the presence of acid, which is more rapid for the encapsulated complex. 


\section{S5.3 Data for Stern-Volmer quenching of $[\operatorname{Ru}(\mathrm{bpy}) 3]^{2+}$ by methyl viologen}

Methyl viologen is a standard quencher for $\left[\mathrm{Ru}(\mathrm{bpy})_{3}\right]^{2+}$ and related complexes, ${ }^{5}$ and the quenching proceeds by an electron transfer mechanism to form the reduced methyl viologen radical cation. A difference in the bimolecular quenching rate constant or the mechanism of quenching (static vs dynamic) between the free and encapsulated complex would indicate that $\mathrm{Q}[10]$ has an effect on the efficiency of the electron transfer. Dynamic quenching is a result of collision between the photosensitizer and the quencher, while static quenching involves energy or electron transfer that is not limited by the diffusion of the molecules (e.g. in preorganized systems). The results are plotted in the manuscript and the raw data is provided here.

In the presence of $\mathrm{Q}[10]$, more than one quenching mechanism is present. The binding affinity of $\mathrm{MV}^{2+}$ in $\left[\mathrm{Ru}(\mathrm{bpy})_{3}\right]^{2+} \subset \mathrm{Q}[10]$ appears to be such that, at the concentrations used in the experiment, the complete formation of the ternary complex is not achieved until a 500-fold excess of the quencher is present $(\sim 4 \mathrm{mM})$. At lower $\mathrm{MV}^{2+}$ concentrations, a dynamic quenching mechanism dominates, and the observed emission intensity and lifetimes are similar to that of the free complex. At higher $\mathrm{MV}^{2+}$ concentrations, the quenching proceeds by a static mechanism, where the photocatalyst is being quenched by an $\mathrm{MV}^{2+}$ molecule which is already associated with the complex.

Table S2. Time-resolved and steady-state emission data for the quenching of $\left[\mathrm{Ru}(\mathrm{bpy})_{3}\right]^{2+}$ by $\mathrm{MV}^{2+}$ in water $(298 \mathrm{~K}$, $8 \mu \mathrm{M}){ }^{a}$

\begin{tabular}{|c|c|c|c|c|}
\hline$\left[\mathbf{M V}^{2+}\right] / \mathbf{m M}$ & $\boldsymbol{\tau} / \mathbf{n s}$ & $\boldsymbol{\tau} \mathbf{0} / \boldsymbol{\tau}$ & $\boldsymbol{I} / \mathbf{1 0}^{\mathbf{5}} \mathbf{C P S}$ & $\boldsymbol{I} \mathbf{0} / \mathbf{I}$ \\
\hline 0 & 550 & 1 & 16.3 & 1 \\
\hline 1.5 & 391 & 1.4 & 12.2 & 1.3 \\
\hline 3.0 & 283 & 1.9 & 8.9 & 1.8 \\
\hline 4.4 & 211 & 2.6 & 6.6 & 2.5 \\
\hline 5.8 & 164 & 3.4 & 5.0 & 3.3 \\
\hline 7.2 & 135 & 4.1 & 4.2 & 3.9 \\
\hline
\end{tabular}

${ }^{a}$ Solutions were sparged with argon prior to the measurement.

Table S3. Time-resolved and steady-state emission data for the quenching of $\left[\mathrm{Ru}(\mathrm{bpy})_{3}\right]^{2+} \subset \mathrm{Q}[10]$ by $\mathrm{MV}^{2+}$ in water $(298 \mathrm{~K}, 8 \mu \mathrm{M}){ }^{a}$

\begin{tabular}{|c|c|c|c|c|}
\hline$\left[\mathbf{M V}^{2+}\right] / \mathbf{m M}$ & $\boldsymbol{\tau} / \mathbf{n S}$ & $\boldsymbol{\tau}_{0} / \boldsymbol{\tau}$ & $\boldsymbol{I} / \mathbf{1 0}^{\mathbf{5}} \mathbf{C P S}$ & $\boldsymbol{I}_{\mathbf{0}} / \boldsymbol{I}$ \\
\hline 0 & 132 & 1 & 4.6 & 1 \\
\hline 1.6 & 87 & 1.5 & 2.8 & 1.7 \\
\hline 3.2 & 66 & 2.0 & 2.1 & 2.2 \\
\hline 4.7 & 61 & 2.1 & 1.8 & 2.5 \\
\hline 6.1 & 61 & 2.1 & 1.6 & 2.8 \\
\hline 7.6 & 65 & 2.0 & 1.5 & 3.0 \\
\hline
\end{tabular}

\footnotetext{
${ }^{a}$ Solutions were sparged with argon prior to the measurement.
} 


\section{S6. Electrochemical data}

\section{S6.1 Oxidation potentials of the complexes}

Table S4. Summary of oxidation potentials in water unless otherwise specified. ${ }^{a}$

\begin{tabular}{|c|c|c|c|c|c|c|}
\hline Species & $\begin{array}{c}E_{1 / 2} \text { or } \\
E_{\mathrm{p}, \mathrm{a}} / \mathrm{V} \\
\quad v s \\
\mathrm{Ag} / \mathrm{AgCl}\end{array}$ & $\begin{array}{l}\text { Emission } \\
\lambda_{\max } / \mathrm{nm}\end{array}$ & $\begin{array}{l}\text { Emission } \\
\lambda_{\max } / \mathrm{eV}\end{array}$ & $\begin{array}{c}E(3+/ 2+*) / \\
\mathrm{V} v s \\
\mathrm{Ag} / \mathrm{AgCl}\end{array}$ & $\begin{array}{c}E(3+/ 2+*) \\
/ \mathrm{V} v s \\
\mathrm{SCE}^{b}\end{array}$ & $\begin{array}{c}E(3+/ 2+*) \\
/ \mathrm{V} \text { vs SCE } \\
(\mathrm{MeCN})^{c}\end{array}$ \\
\hline$\left[\mathrm{Ru}(\mathrm{bpy})_{3}\right] \mathrm{Cl}_{2}$ & +1.081 & 616 & 2.01 & -0.93 & -0.97 & -0.73 \\
\hline $\begin{array}{l}{\left[\mathrm{Ru}(\mathrm{bpy})_{3}\right] \mathrm{Cl}_{2} \text { in }} \\
\mathrm{Q}[10]\end{array}$ & +1.091 & 604 & 2.05 & -0.96 & -1.00 & - \\
\hline$\left[\mathrm{Ru}(\mathrm{bpy})_{2}(\mathrm{bpm})\right] \mathrm{Cl}_{2}$ & $+1.317^{\mathrm{irr}}$ & 705 & 1.76 & -0.44 & -0.48 & -0.42 \\
\hline $\begin{array}{l}{\left[\mathrm{Ru}(\mathrm{bpy})_{2}(\mathrm{bpm})\right] \mathrm{Cl}_{2}} \\
\text { in } \mathrm{Q}[10]\end{array}$ & $+1.327^{\mathrm{irr}}$ & 686 & 1.81 & -0.48 & -0.52 & - \\
\hline$\left[\mathrm{Ru}(\mathrm{bpy})_{2}(\mathrm{bpz})\right] \mathrm{Cl}_{2}$ & $+1.418^{\mathrm{irr}}$ & 716 & 1.73 & -0.31 & -0.35 & -0.25 \\
\hline $\begin{array}{l}{\left[\mathrm{Ru}(\mathrm{bpy})_{2}(\mathrm{bpz})\right] \mathrm{Cl}_{2}} \\
\text { in } \mathrm{Q}[10]\end{array}$ & $+1.448^{\mathrm{irr}}$ & 694 & 1.79 & -0.34 & -0.37 & - \\
\hline
\end{tabular}

${ }^{a}$ Potentials were measured in water with phosphate buffer $(0.1 \mathrm{M}, \mathrm{pH} 7)$ as the electrolyte using a glassy carbon working electrode, $\mathrm{Pt}$ wire counter electrode and $\mathrm{Ag} / \mathrm{AgCl}$ reference electrode. ${ }^{b}$ Conversion between $\mathrm{Ag} / \mathrm{AgCl}(3.5 \mathrm{M} \mathrm{KCl})$ and SCE was calculated as $-0.035 \mathrm{~V} .{ }^{6}{ }^{c}$ Taken from electrochemical and emission values measured in $\mathrm{MeCN} \mathrm{using}$ the $\mathrm{PF}_{6}$ salts of these complexes. Potentials in $\mathrm{MeCN}$ were measured with $0.1 \mathrm{M} \mathrm{TBAPF}_{6}$ as the supporting electrolyte. Potentials were converted from a Fc to SCE reference by adding $380 \mathrm{mV}$. $^{7}$ 


\section{S6.2 Mechanism of heterogeneous electron transfer from $[R u(b p y) 3]^{2+}$}

A method for determining the mechanism of the electron transfer is to monitor the reversibility of the process with increasing scan rates. If the electron transfer occurs while the complex is bound within the macrocycle, the voltammogram should appear reversible at high scan rates. That is, the shape of the voltammogram should appear the same as that of the unbound complex at high scan rates. The mechanism that involves the electron transfer outside the macrocycle should be limited by the rate of dissociation at high scan rates, which can result in a distortion of the shape of the voltammogram.

a)

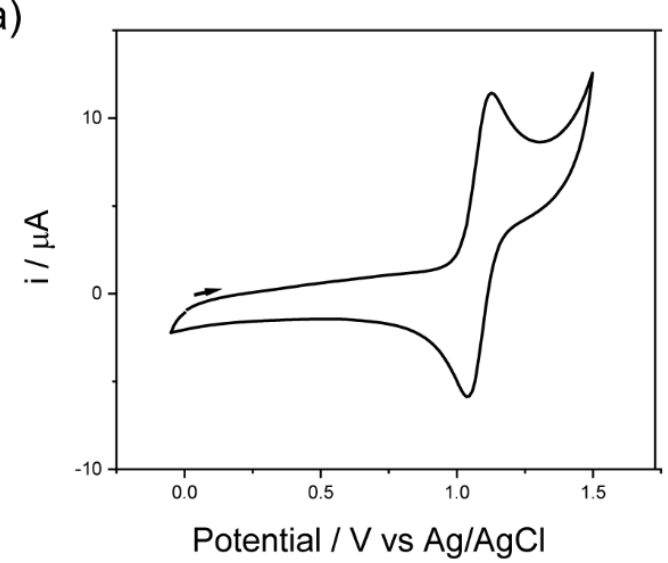

c)

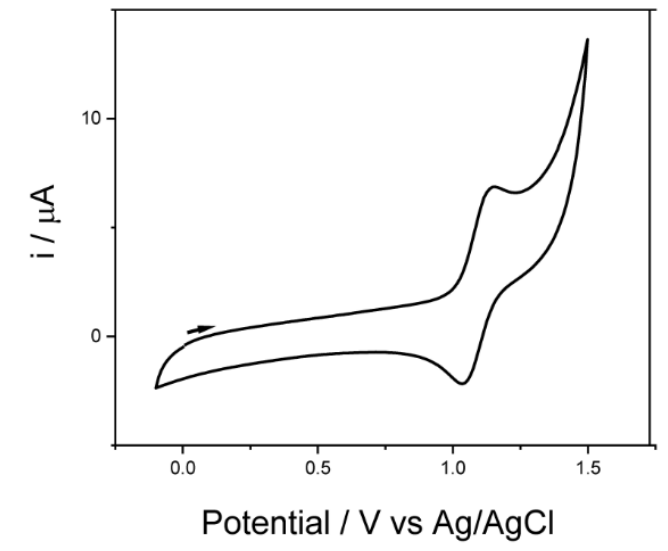

b)

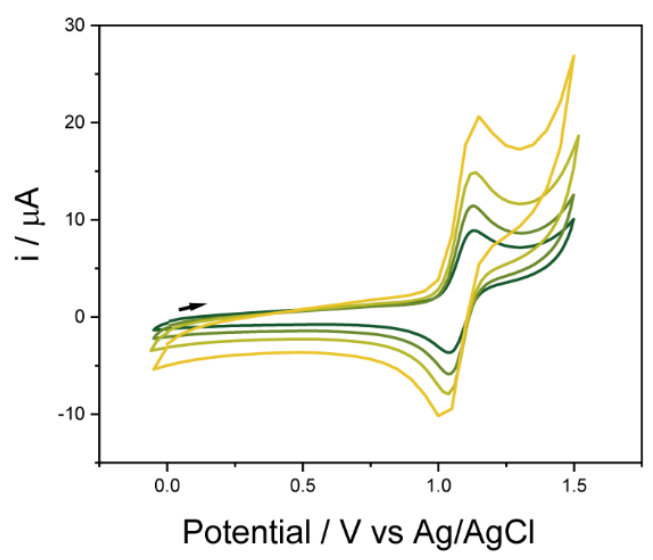

d)

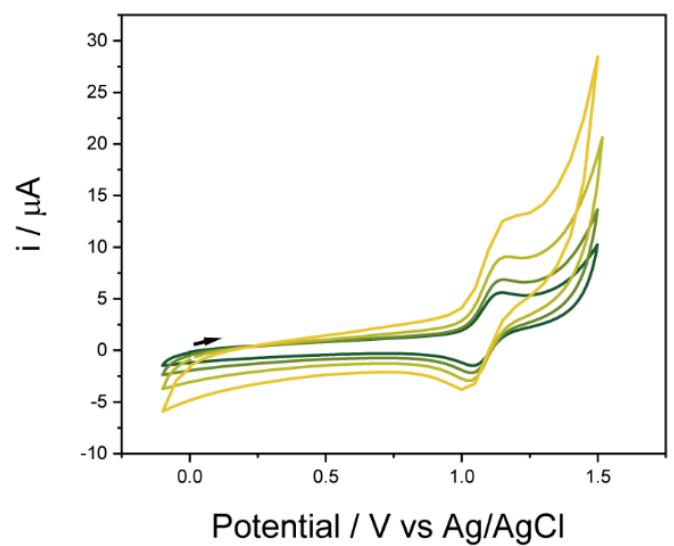

Figure S26. Cyclic voltammograms showing the $\mathrm{Ru}^{\mathrm{IIIIII}}$ couple of free and encapsulated $\left[\mathrm{Ru}(\mathrm{bpy})_{3}\right]^{2+}$ in aqueous solution containing $0.1 \mathrm{M}$ phosphate buffer as the supporting electrolyte. The oxidation of $\left[\mathrm{Ru}(\mathrm{bpy})_{3}\right]^{2+} \subset \mathrm{Q}[10]$ did not remain reversible at high scan rates, indicating that the complex dissociates from the macrocycle before the electron transfer. a)-b): free $\left[\mathrm{Ru}(\mathrm{bpy})_{3}\right]^{2+}$; a) $v=100 \mathrm{mV} \mathrm{s}^{-1} ; E_{1 / 2}=+1.081 \mathrm{~V}, \Delta \mathrm{V}=90 \mathrm{mV}$; b) measured at increasing scan rates: $v=50$ $\mathrm{mV} \mathrm{s}^{-1}$ (green), $100 \mathrm{mV} \mathrm{s}^{-1}, 200 \mathrm{mV} \mathrm{s}^{-1}, 500 \mathrm{mV} \mathrm{s}^{-1}$ (yellow). c)-d): $\left[\mathrm{Ru}(\text { bpy) })_{3}\right]^{2+} \subset \mathrm{Q}[10]$; c) $v=100 \mathrm{mV} \mathrm{s}^{-1} ; E_{1 / 2}=+1.091$ $\mathrm{V}, \Delta \mathrm{V}=112 \mathrm{mV}$; d) measured at increasing scan rates: $v=50 \mathrm{mV} \mathrm{s}^{-1}$ (green), $100 \mathrm{mV} \mathrm{s}^{-1}, 200 \mathrm{mV} \mathrm{s}^{-1}, 500 \mathrm{mV} \mathrm{s}^{-1}$ (yellow). 


\section{S6.3 Spectroelectrochemistry}

a)

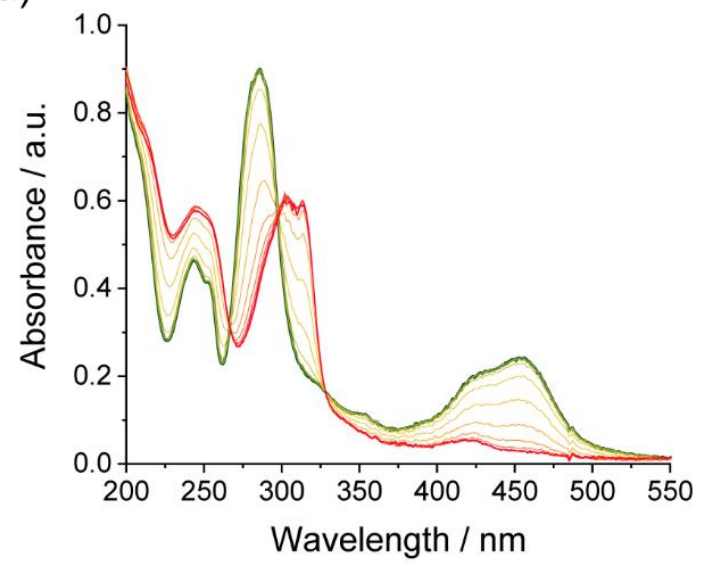

b)

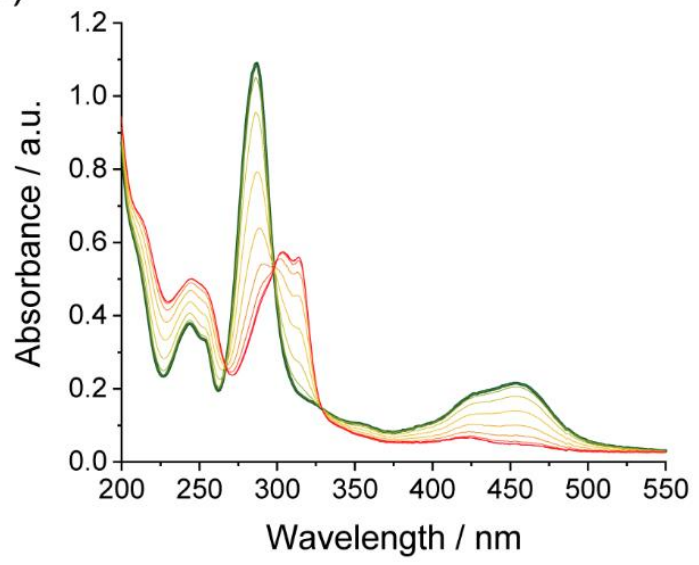

Figure S27. Changes in the absorption spectra $\left(\mathrm{H}_{2} \mathrm{O}, 298 \mathrm{~K}\right)$ upon the oxidation of free and encapsulated $\left[\mathrm{Ru}(\mathrm{bpy})_{3}\right]^{2+}$. The final absorption spectra of both species are in agreement with the reported spectrum ${ }^{8}$ of $\left[\operatorname{Ru}(b p y)_{3}\right]^{3+}$ and show that $\mathrm{Q}[10]$ does not significantly affect the oxidized complex. The spectra were collected in $\mathrm{H}_{2} \mathrm{O}$ containing $0.1 \mathrm{M}$ phosphate buffer ( $\mathrm{pH} 7)$ in an OTTLE cell fitted with a platinum mesh, platinum wire and silver wire as working, counter and reference electrodes respectively. a) Free $\left[\mathrm{Ru}(\mathrm{bpy})_{3}\right]^{2+}$; the spectra shown are between $0.75 \mathrm{~V}$ (green) and $1.35 \mathrm{~V}$ (red) $v s$ a silver wire electrode. b) $\left[\mathrm{Ru}(\mathrm{bpy})_{3}\right]^{2+} \subset \mathrm{Q}[10]$; the spectra shown are between $0.75 \mathrm{~V}$ (green) and $1.00 \mathrm{~V}$ (red) $v s$ a silver wire electrode. The spectra were collected at $0.05 \mathrm{~V}$ intervals and the time between scans is approximately $10 \mathrm{~s}$. 
a)

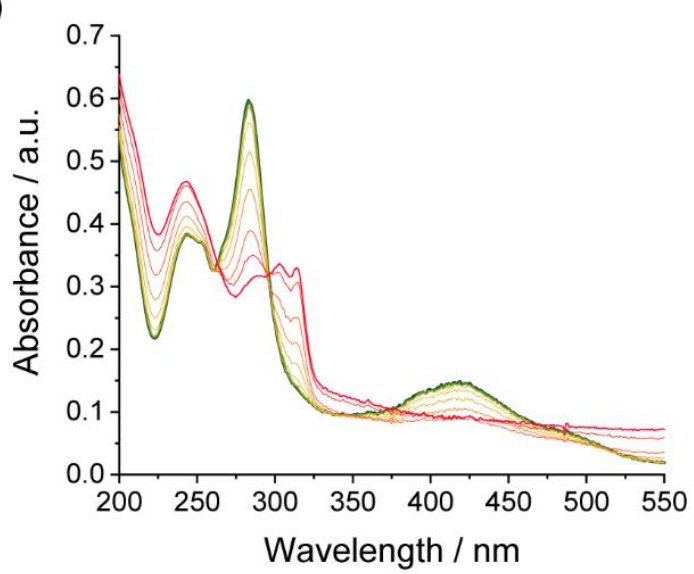

c)

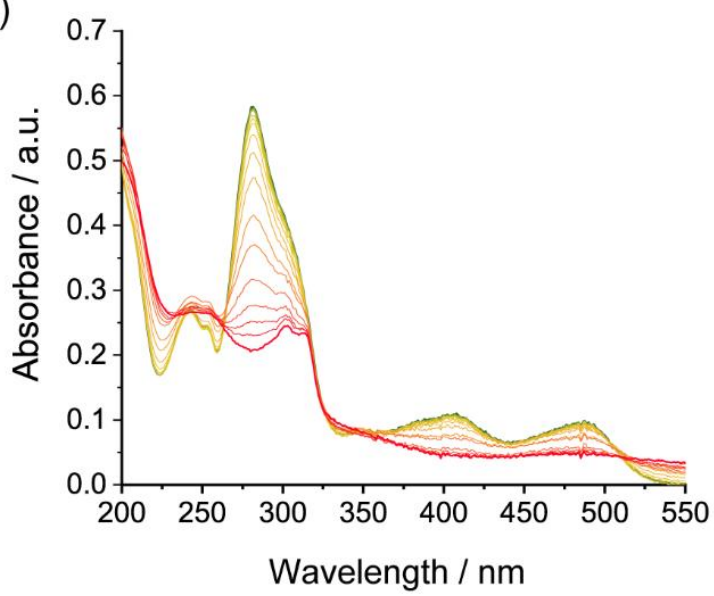

b)

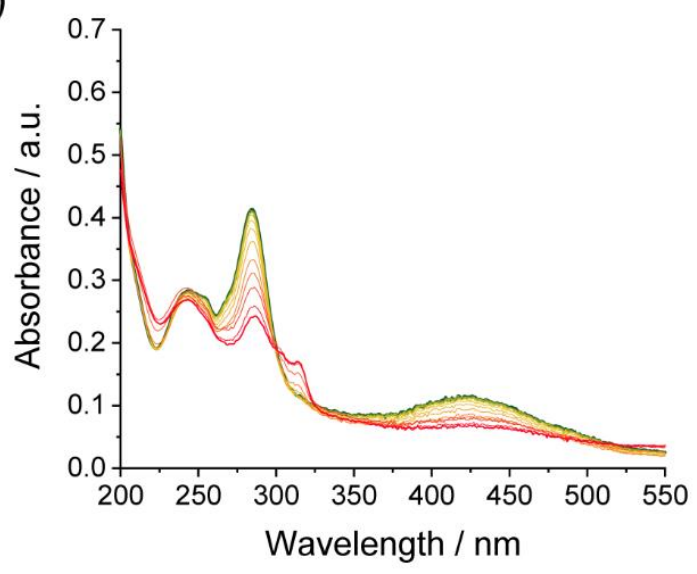

d)

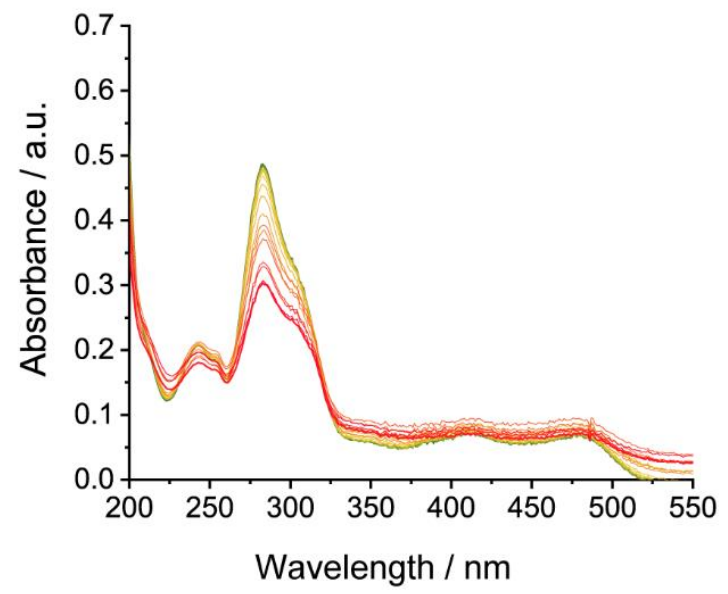

Figure S28. Changes in the absorption spectra $\left(\mathrm{H}_{2} \mathrm{O}, 298 \mathrm{~K}\right)$ upon the oxidation of free and encapsulated $\left[\mathrm{Ru}(\mathrm{bpy})_{2}(\mathrm{bpm})\right]^{2+}$ and $\left[\mathrm{Ru}(\mathrm{bpy})_{2}(\mathrm{bpz})\right]^{2+}$. Unlike $\left[\mathrm{Ru}(\mathrm{bpy})_{3}\right]^{2+}$, the changes in the absorption spectra are inconsistent between the free and encapsulated complexes as they are oxidized. The decrease in intensity of the bands corresponding to the $\mathrm{Ru}^{\mathrm{II}}$ species is slower when the complex is encapsulated in $\mathrm{Q}[10]$, suggesting that the macrocycle affects the oxidation process. However, redox potentials measured by cyclic voltammetry suggest otherwise. The spectra were collected in $\mathrm{H}_{2} \mathrm{O}$ containing $0.1 \mathrm{M}$ phosphate buffer ( $\mathrm{pH}$ 7) in an OTTLE cell fitted with a platinum mesh, platinum wire and silver wire as working, counter and reference electrodes respectively. a) Free $\left[\mathrm{Ru}(\mathrm{bpy})_{2}(\mathrm{bpm})\right]^{2+}$; the spectra shown are between $0.75 \mathrm{~V}$ (green) and $1.20 \mathrm{~V}$ (red) $v s$ silver wire. b) $\left[\mathrm{Ru}(\mathrm{bpy})_{2}(\mathrm{bpm})\right]^{2+} \subset \mathrm{Q}[10]$; the spectra shown are between $0.75 \mathrm{~V}$ (green) and $1.55 \mathrm{~V}$ (red) $v s$ silver wire. c) Free $\left[\mathrm{Ru}(\mathrm{bpy})_{2}(\mathrm{bpz})\right]^{2+}$; the spectra shown are between $0.75 \mathrm{~V}$ (green) and $1.65 \mathrm{~V}$ (red) $v s$ silver wire. d) $\left[\mathrm{Ru}(\mathrm{bpy})_{2}(\mathrm{bpz})\right]^{2+} \subset \mathrm{Q}[10]$; the spectra shown are between $0.75 \mathrm{~V}$ (green) and $1.65 \mathrm{~V}$ (red) $v s$ silver wire. The spectra were collected at $0.05 \mathrm{~V}$ intervals and the time between scans is approximately $10 \mathrm{~s}$. 


\section{S7. Substrate binding}

\section{S7.1 ${ }^{1} \mathrm{H}$ NMR studies}

Table S5. Summary of screening for substrate binding. ${ }^{a}$

\begin{tabular}{|c|c|c|c|c|}
\hline Entry & Guest & $\begin{array}{l}\text { Changes in the } \\
{ }^{1} \mathrm{H} \text { NMR signals } \\
\text { of }\left[\mathrm{Ru}(\mathrm{bpy})_{3}\right]^{2+}\end{array}$ & $\begin{array}{c}\text { Changes in the }{ }^{1} \mathrm{H} \\
\text { NMR signals of } \\
\text { guests }\end{array}$ & $\begin{array}{c}\text { Suitable } \\
\text { guest? }\end{array}$ \\
\hline 1 & & No change & Downfield & No \\
\hline 2 & & $\begin{array}{c}\text { Y3 shifted downfield } \\
\text { (slight) } \\
\text { Y4, Y6, Y5: no } \\
\text { change }\end{array}$ & Upfield & Yes \\
\hline 3 & & $\begin{array}{l}\text { Y3, Y4, Y6 shifted } \\
\text { downfield } \\
\text { Y5 shifted upfield } \\
\text { (slight) }\end{array}$ & $\begin{array}{c}\text { Upfield } \\
\text { Resolution of phenyl } \\
\text { peaks }\end{array}$ & Yes \\
\hline 4 & & $\begin{array}{l}\text { Y3, Y4, Y6 shifted } \\
\text { downfield } \\
\text { Y5 shifted upfield }\end{array}$ & Upfield & Yes \\
\hline 5 & & $\begin{array}{l}\text { Y6 and Y5: } \\
\text { broadened } \\
\text { Y3 and Y4: no } \\
\text { change }\end{array}$ & $\begin{array}{c}\text { Free guest is insoluble } \\
\text { in } \mathrm{D}_{2} \mathrm{O} \text {; some (broad) } \\
\text { peaks visible in } \mathrm{HG} \\
\text { complex }\end{array}$ & No \\
\hline 6 & & No change & Upfield, broadened & No \\
\hline 7 & & $\begin{array}{c}\text { Y3, Y4, Y6 shifted } \\
\text { downfield } \\
\text { Y5: no change }\end{array}$ & $\begin{array}{l}\text { Upfield, some signals } \\
\text { broadened }\end{array}$ & Yes \\
\hline 8 & & $\begin{array}{l}\text { Y3, Y4, Y6 shifted } \\
\text { downfield (slight) } \\
\text { Y5: no change }\end{array}$ & Slight upfield shift & No \\
\hline 9 & $2 \mathrm{Cl}^{-}$ & $\begin{array}{c}\text { Y3 shifted downfield } \\
\text { Y4, Y6: no change } \\
\text { Y5 shifted slightly } \\
\text { upfield }\end{array}$ & $\begin{array}{l}\text { Upfield, some signals } \\
\text { broadened }\end{array}$ & Yes \\
\hline
\end{tabular}

${ }^{a}$ Results were obtained by ${ }^{1} \mathrm{H}$ NMR spectroscopy in $\mathrm{D}_{2} \mathrm{O}$. All solutions contained 1:1:1 mixtures with each of the three components at $3 \mathrm{mM}$. Although there were some changes in the signals corresponding to $\left[\mathrm{Ru}(\mathrm{bpy})_{3}\right]^{2+}$, none of the signals present matched those expected for free $\left[\mathrm{Ru}(\mathrm{bpy})_{3}\right]^{2+}$, indicating that the complex remains bound in $\mathrm{Q}[10]$ in the presence of added guest. 


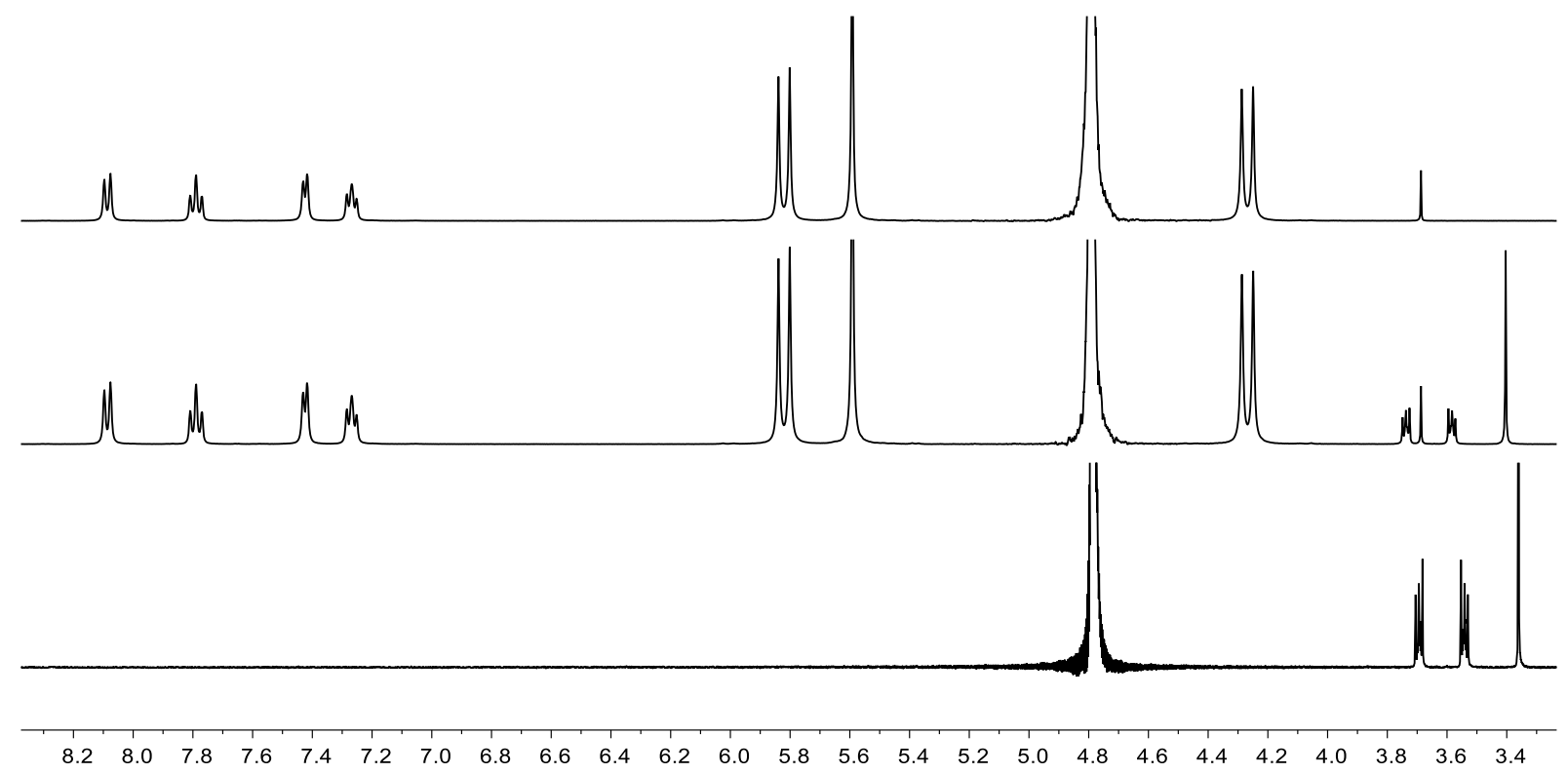

Figure S29. Partial ${ }^{1} \mathrm{H}$ NMR spectra $\left(400 \mathrm{MHz}, \mathrm{D}_{2} \mathrm{O}\right)$ of (top to bottom): $\left[\mathrm{Ru}(\mathrm{bpy})_{3}\right]^{2+} \subset \mathrm{Q}[10]$; $1: 1: 1$ mixture of $\left[\mathrm{Ru}(\mathrm{bpy})_{3}\right]^{2+} \subset \mathrm{Q}[10]$ and 2-methoxyethanol; unbound 2-methoxyethanol (Table S5, entry 1).

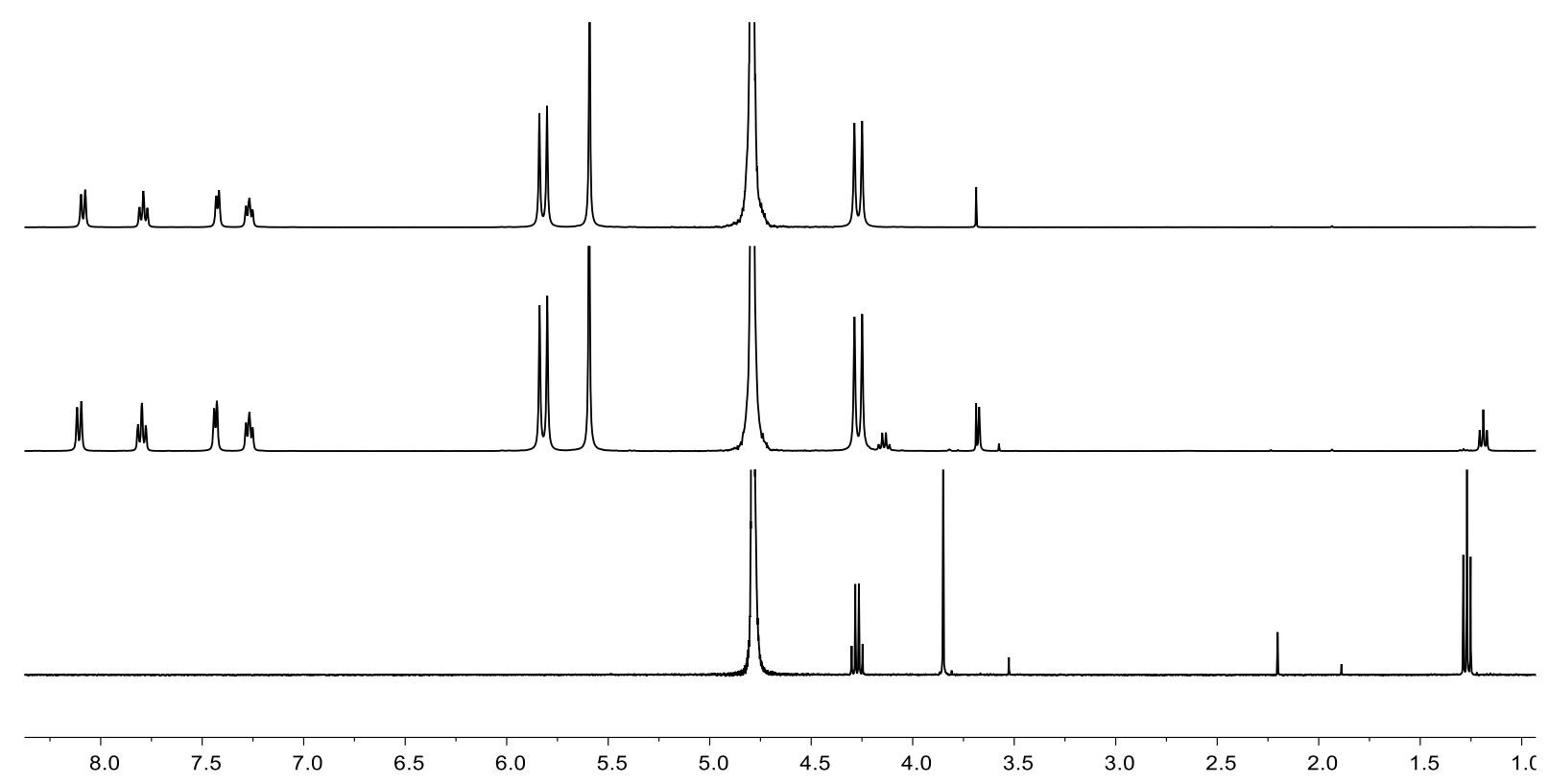

Figure S30. Partial ${ }^{1} \mathrm{H}$ NMR spectra $\left(400 \mathrm{MHz}, \mathrm{D}_{2} \mathrm{O}\right.$ ) of (top to bottom): $\left[\mathrm{Ru}(\mathrm{bpy})_{3}\right]^{2+} \subset \mathrm{Q}[10]$; 1:1:1 mixture of $\left[\mathrm{Ru}(\text { bpy })_{3}\right]^{2+} \subset \mathrm{Q}[10]$ and glycine ethyl ester hydrochloride; unbound glycine ethyl ester hydrochloride (Table S5, entry 2). 


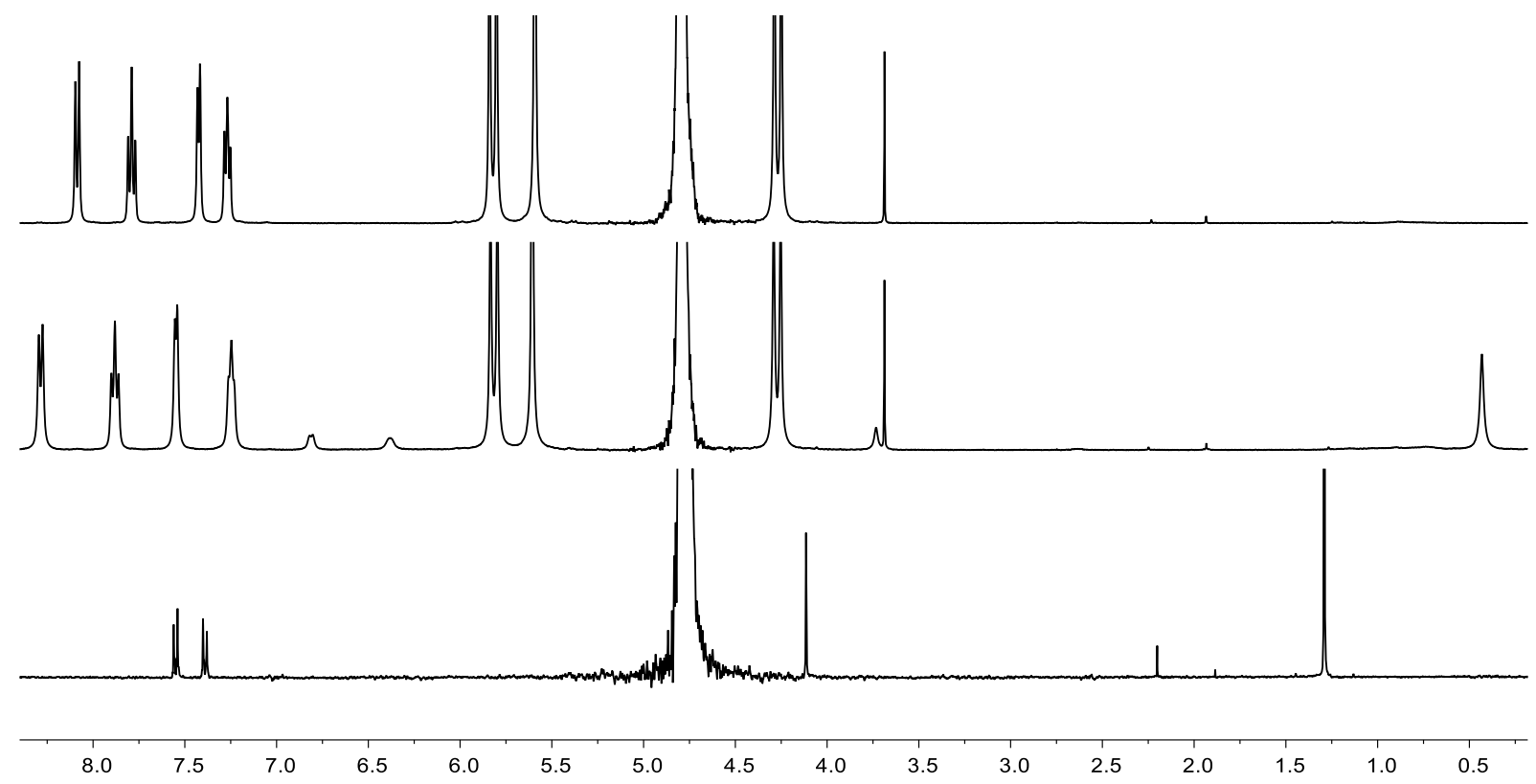

Figure S31. Partial ${ }^{1} \mathrm{H}$ NMR spectra $\left(400 \mathrm{MHz}, \mathrm{D}_{2} \mathrm{O}\right.$ ) of (top to bottom): $\left[\mathrm{Ru}(\mathrm{bpy})_{3}\right]^{2+} \subset \mathrm{Q}[10]$; 1:1:1 mixture of $\left[\mathrm{Ru}(\mathrm{bpy})_{3}\right]^{2+} \subset \mathrm{Q}[10]$ and 4-tert-butylbenzylamine hydrochloride; unbound 4-tert-butylbenzylamine hydrochloride (Table S5, entry 4).

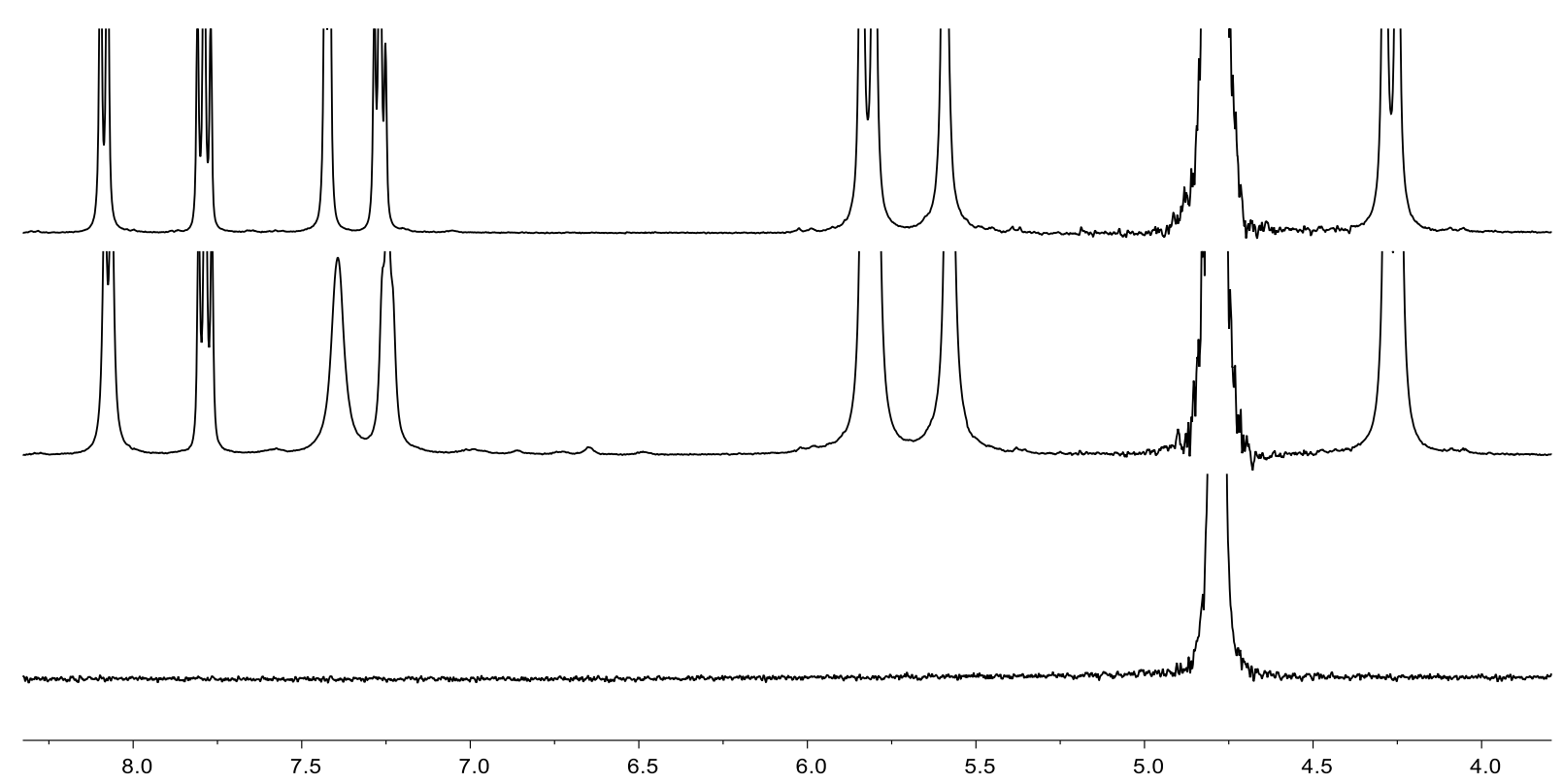

Figure S32. Partial ${ }^{1} \mathrm{H}$ NMR spectra $\left(400 \mathrm{MHz}, \mathrm{D}_{2} \mathrm{O}\right)$ of (top to bottom): $\left[\mathrm{Ru}(\mathrm{bpy})_{3}\right]^{2+} \subset \mathrm{Q}[10]$; $1: 1: 1$ mixture of $\left[\mathrm{Ru}(\mathrm{bpy})_{3}\right]^{2+} \subset \mathrm{Q}[10]$ and 2-aminoanthracene; unbound (insoluble) 2-aminoanthracene (Table S5, entry 5). 


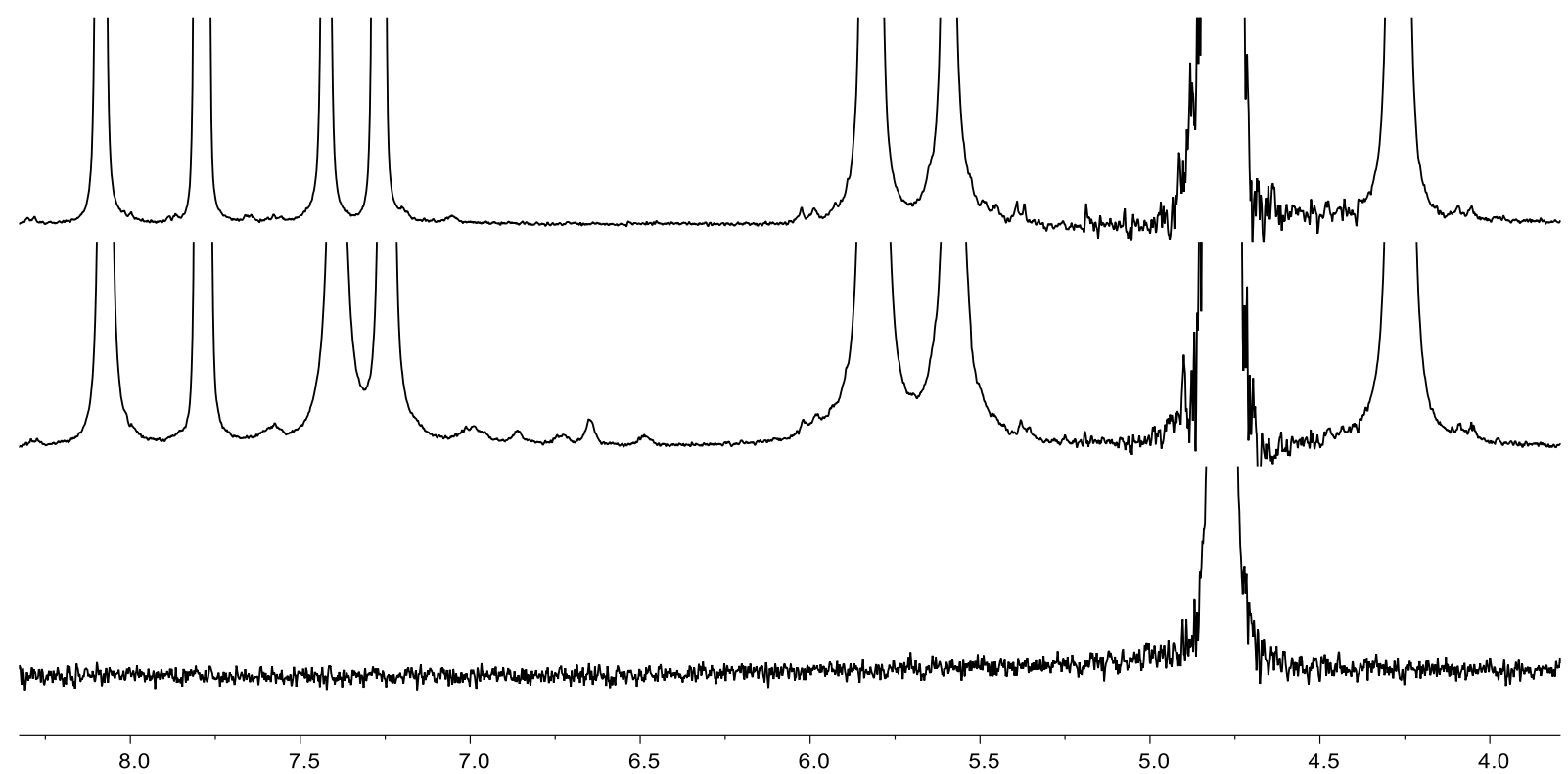

Figure S33. Magnification of Figure S32 showing the small peaks due to bound 2-amino anthracene between 7.0 and 6.5 ppm in the middle spectrum.

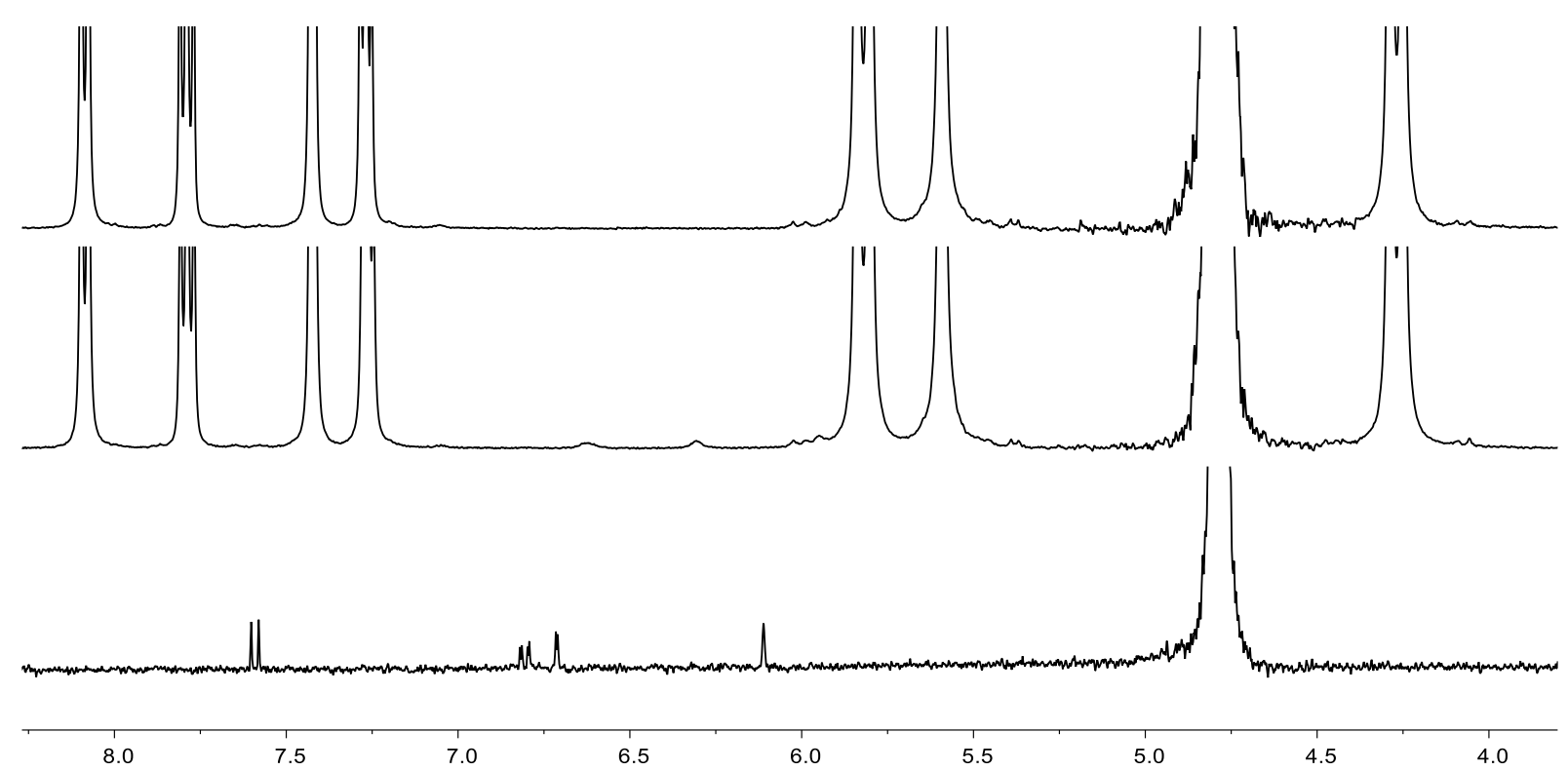

Figure S34. Partial ${ }^{1} \mathrm{H}$ NMR spectra $\left(400 \mathrm{MHz}, \mathrm{D}_{2} \mathrm{O}\right.$ ) of (top to bottom): $\left[\mathrm{Ru}(\mathrm{bpy})_{3}\right]^{2+} \subset \mathrm{Q}[10]$; 1:1:1 mixture of $\left[\mathrm{Ru}(\mathrm{bpy})_{3}\right]^{2+} \subset \mathrm{Q}[10]$ and 7-amino-4-methylcoumarin; unbound 7-amino-4-methylcoumarin (Table S5, entry 6). 


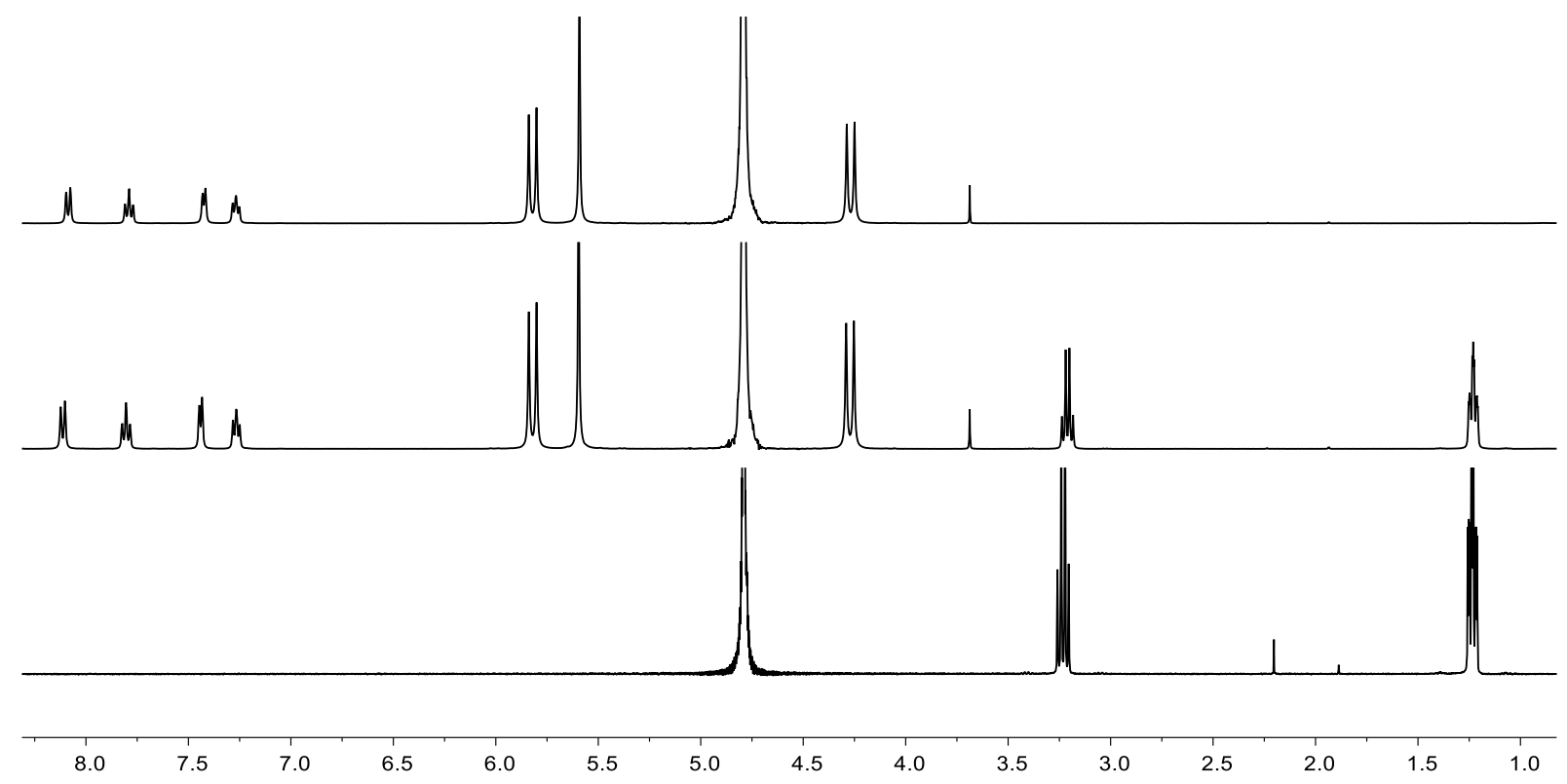

Figure S35. Partial ${ }^{1} \mathrm{H}$ NMR spectra $\left(400 \mathrm{MHz}, \mathrm{D}_{2} \mathrm{O}\right)$ of (top to bottom): $\left[\mathrm{Ru}(\mathrm{bpy})_{3}\right]^{2+} \subset \mathrm{Q}[10]$; $1: 1: 1$ mixture of $\left[\mathrm{Ru}(\mathrm{bpy})_{3}\right]^{2+} \subset \mathrm{Q}[10]$ and tetraethylammonium chloride; unbound tetraethylammonium chloride (Table S5, entry 8).

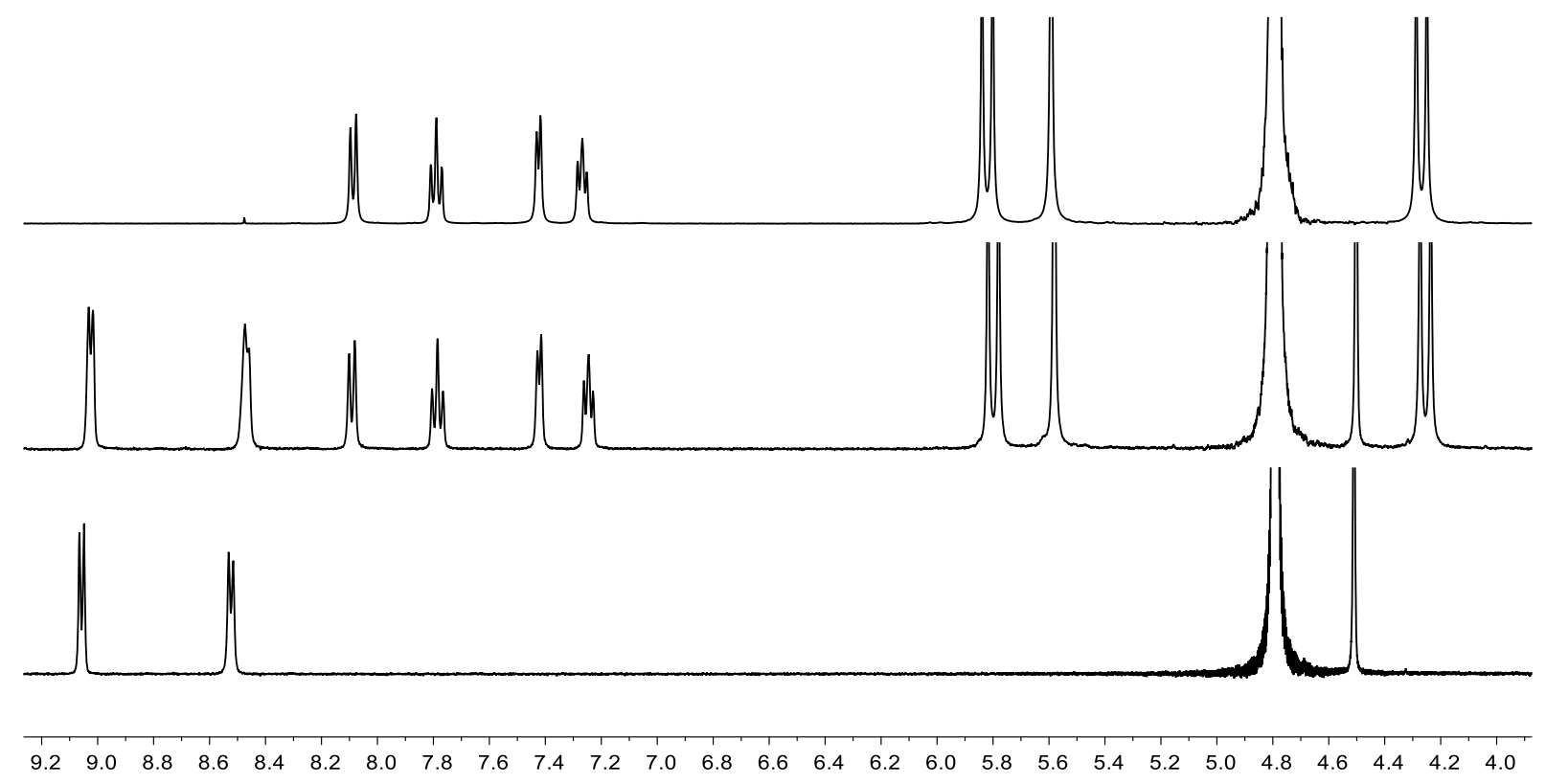

Figure S36. Partial ${ }^{1} \mathrm{H}$ NMR spectra $\left(400 \mathrm{MHz}, \mathrm{D}_{2} \mathrm{O}\right.$ ) of (top to bottom): $\left[\mathrm{Ru}(\mathrm{bpy})_{3}\right]^{2+} \subset \mathrm{Q}[10]$; 1:1:1 mixture of $\left[\mathrm{Ru}(\mathrm{bpy})_{3}\right]^{2+} \subset \mathrm{Q}[10]$ and methyl viologen; unbound methyl viologen (Table S5, entry 9). 


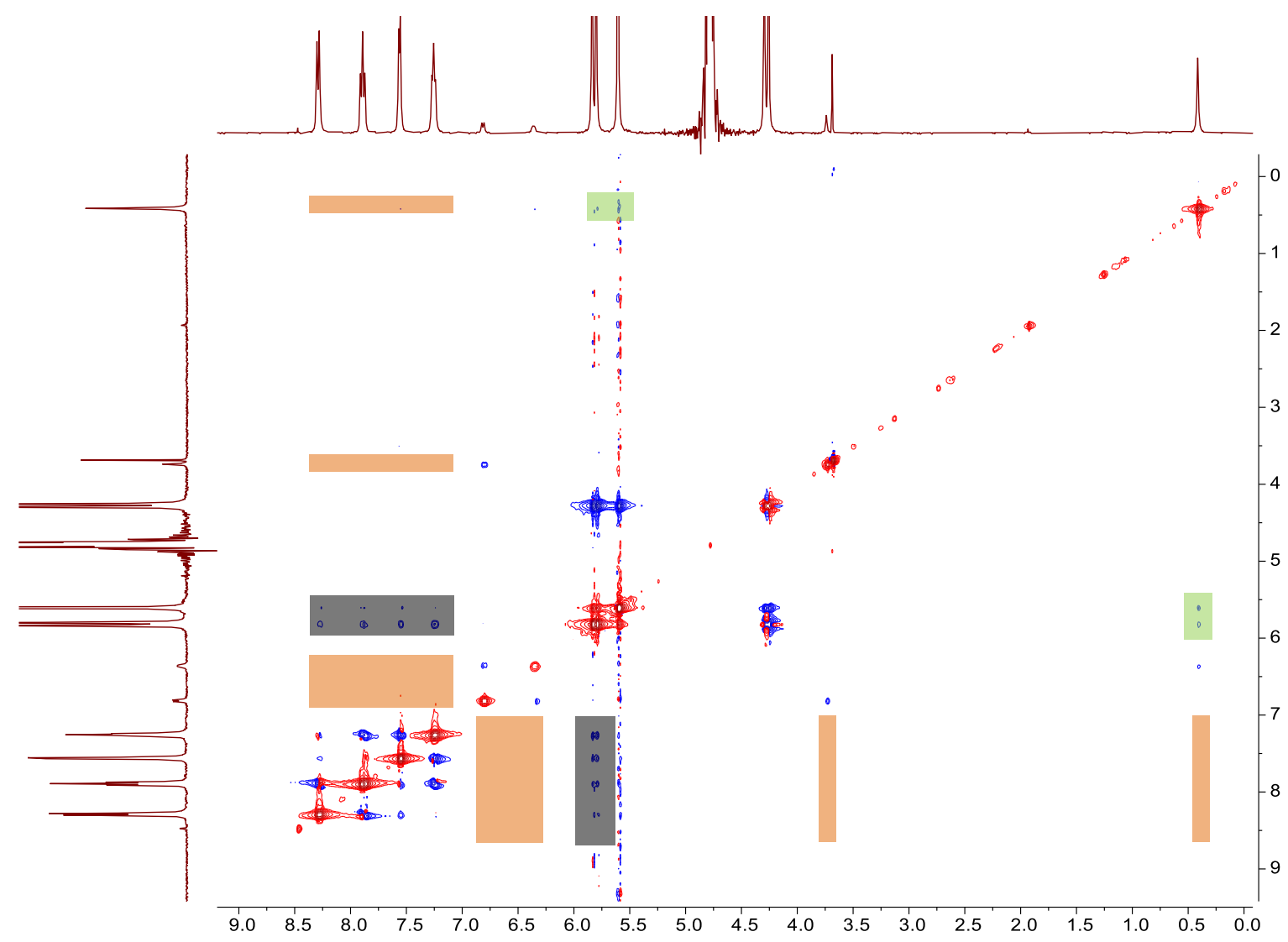

Figure S37. ROESY spectrum $\left(400 \mathrm{MHz}, \mathrm{D}_{2} \mathrm{O}\right)$ of a $1: 1$ mixture of $\left[\mathrm{Ru}(\mathrm{bpy})_{3}\right]^{2+} \subset \mathrm{Q}[10]$ and 4-tert-butylbenzylamine hydrochloride as a guest molecule. The observed cross-peaks are due to correlations between $\left[\mathrm{Ru}(\mathrm{bpy})_{3}\right]^{2+}$ and $\mathrm{Q}[10]$ (example shown in grey), and between the guest and Q[10] (example shown in green). Although the ternary complex is formed, there were no observable correlations between $\left[\mathrm{Ru}(\mathrm{bpy})_{3}\right]^{2+}$ and the guest, which are expected in the orange regions. This observation suggests that the interactions between the guest and Q[10] are more important for ternary complex formation than the interactions between the guest and the ruthenium complex.

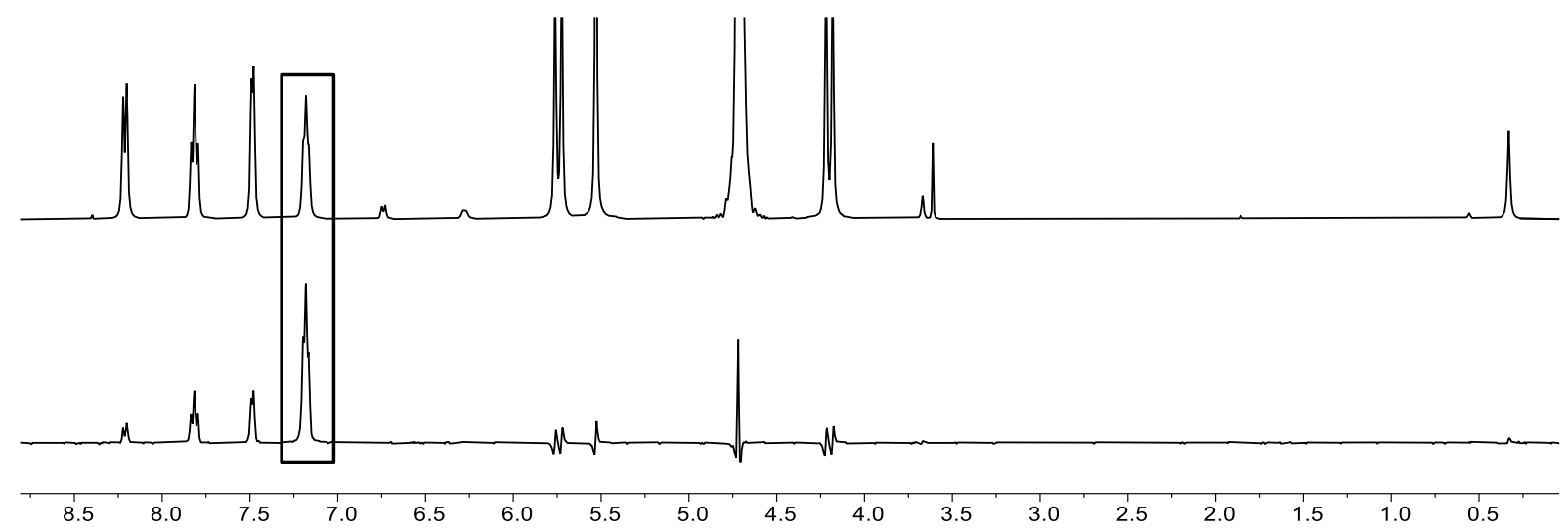

Figure S38. NMR spectra $\left(400 \mathrm{MHz}, \mathrm{D}_{2} \mathrm{O}\right)$ of a $1: 1$ mixture of $\left[\mathrm{Ru}(\mathrm{bpy})_{3}\right]^{2+} \subset \mathrm{Q}[10]$ and 4-tert-butylbenzylamine hydrochloride as a guest molecule. Top: ${ }^{1} \mathrm{H}$ NMR; bottom: 1D selective NOE with irradiation of proton $\mathrm{H}^{\mathrm{Y} 5}$ (black) of $\left[\mathrm{Ru}(\mathrm{bpy})_{3}\right]^{2+}$. The observed intermolecular interactions are with Q[10] only, in agreement with the ROESY data above. 


\section{S8. Diphenyliodonium as a catalysis substrate}

\section{S8.1 Stern-Volmer quenching of $\left[\operatorname{Ru}(\mathrm{bpy})_{3}\right]^{2+}$ by diphenyliodonium}

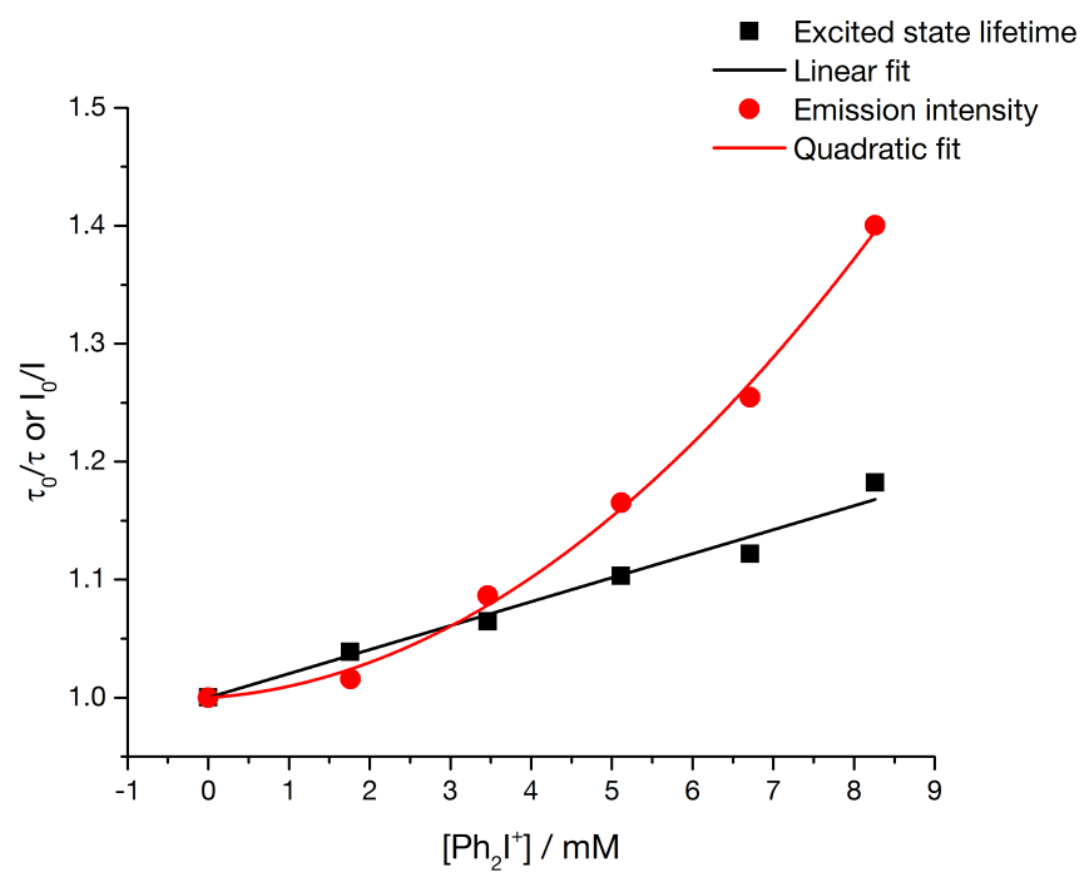

Figure S39. Stern-Volmer quenching plot based on the excited state lifetime and emission intensity $\left(\mathrm{H}_{2} \mathrm{O}, 298 \mathrm{~K}, 8 \mu \mathrm{M}\right)$ of $\left[\mathrm{Ru}(\mathrm{bpy})_{3}\right]^{2+}$ in the presence of $\mathrm{Ph}_{2} \mathrm{I}^{+}$, indicating a combination of static and dynamic quenching mechanisms. From the measured lifetimes, $k_{\mathrm{Q}}=3.6 \times 10^{7} \mathrm{M}^{-1} \mathrm{~s}^{-1}$.

Table S6. Measured lifetimes from the Stern-Volmer quenching of the excited state of free and encapsulated $\left[\mathrm{Ru}(\mathrm{bpy})_{3}\right]^{2+}$ in water with $\mathrm{Ph}_{2} \mathrm{I}^{+}$as quencher. ${ }^{a}$

\begin{tabular}{|c|c|c|}
\hline Added $\mathbf{P h}_{2} \mathbf{I}^{+}$equivalents & $\boldsymbol{\tau}$ with Q[10] / ns & $\boldsymbol{\tau}$ without $\mathbf{Q}[\mathbf{1 0}] / \mathbf{n s}$ \\
\hline 0 & 159 & 572 \\
\hline 200 & 580 & 550 \\
\hline 400 & 565 & 537 \\
\hline 600 & 550 & 518 \\
\hline 800 & 535 & 510 \\
\hline 1000 & 528 & 483 \\
\hline
\end{tabular}

${ }^{a}$ Solutions were made up in $0.01 \mathrm{M}$ phosphate buffer $(\mathrm{pH} 7)$. The solutions were degassed by being sparged with argon prior to the measurement. 


\section{S9. References}

1. Pisani, M. J.; Zhao, Y.; Wallace, L.; Woodward, C. E.; Keene, F. R.; Day, A. I.; Collins, J. G., Cucurbit[10]uril binding of dinuclear platinum(II) and ruthenium(II) complexes: association/dissociation rates from seconds to hours. Dalton Trans. 2010, 39 (8), 2078-2086.

2. Day, A.; Arnold, A. P.; Blanch, R. J.; Snushall, B., Controlling Factors in the Synthesis of Cucurbituril and Its Homologues. J. Org. Chem. 2001, 66 (24), 8094-8100.

3. Nazeeruddin, M. K.; Kalyanasundaram, K., Acid-base behavior in the ground and excited states of ruthenium(II) complexes containing tetraimines or dicarboxybipyridines as protonatable ligands. Inorg. Chem. 1989, 28 (23), 4251-4259.

4. Shinozaki, K.; Kaizu, Y.; Hirai, H.; Kobayashi, H., Protonation and complex formation of [(2,2'-bipyrazine)bis(2,2'-bipyridine)ruthenium(II)](2+) in the lowest excited state. Inorg. Chem. 1989, 28 (19), 3675-3679.

5. Juris, A.; Balzani, V.; Barigelletti, F.; Campagna, S.; Belser, P.; von Zelewsky, A., Ru(II) Polypyridine Complexes: Photophysics, Photochemistry, Electrochemistry, and Chemiluminescence. Coord. Chem. Rev. 1988, 84, 85-277.

6. Bard, A. J., Electrochemical methods : fundamentals and applications. 2nd ed. ed.; New York : Wiley: New York, 2001.

7. Pavlishchuk, V. V.; Addison, A. W., Conversion constants for redox potentials measured versus different reference electrodes in acetonitrile solutions at $25^{\circ} \mathrm{C}$. Inorg. Chim. Acta 2000, 298 (1), 97-102.

8. Brown, A. M.; McCusker, C. E.; McCusker, J. K., Spectroelectrochemical identification of charge-transfer excited states in transition metal-based polypyridyl complexes. Dalton Trans. 2014, 43 (47), 17635-17646. 